\title{
Kelps' Long-Distance Dispersal: Role of Ecological/Oceanographic Processes and Implications to Marine Forest Conservation
}

\author{
Manuela Bernardes Batista 1,*(D), Antônio Batista Anderson ${ }^{1}$, Paola Franzan Sanches ${ }^{2}$, \\ Paulo Simionatto Polito ${ }^{3}{ }^{(1)}$, Thiago Cesar Lima Silveira ${ }^{1}$, Gabriela M. Velez-Rubio ${ }^{4}$, \\ Fabrizio Scarabino ${ }^{4}$, Olga Camacho ${ }^{5}$, Caroline Schmitz ${ }^{5}$, Ana Martinez ${ }^{6}$, Leonardo Ortega ${ }^{6}$,
} Graciela Fabiano ${ }^{6}$, Mark D. Rothman ${ }^{7}$, Gang Liu ${ }^{8,9}$, Jaime Ojeda ${ }^{10}$, Andrés Mansilla ${ }^{10}$, Luis M. Barreto ${ }^{11}$, Jorge Assis ${ }^{11}$ (D), Ester A. Serrão ${ }^{11}{ }^{(1)}$, Rui Santos ${ }^{11}$ and Paulo Antunes Horta ${ }^{1}$

1 Programa de Pós-Graduação em Ecologia, Universidade Federal de Santa Catarina, Florianópolis, SC 88040-900, Brazil; aabbiologia@gmail.com (A.B.A.); silveira.tcl@gmail.com (T.C.L.S.); paulo.horta@ufsc.br (P.A.H.)

2 Instituto Oceanográfico, Departamento de Oceanografia Biológica, Praça do Oceanográfico, Universidade de São Paulo, 112 Butantã, São Paulo, SP 05508120, Brazil; paolafsanches@gmail.com

3 Instituto Oceanográfico, Departamento de Oceanografia Física, Química e Geológica, Praça do Oceanográfico, Universidade de São Paulo, 172 Butantã, São Paulo, SP 05508120, Brazil; polito@usp.br

4 Centro Universitario Regional del Este (CURE), Universidad de la República, Intersección Ruta 9 y Ruta 15, Rocha 27000, Uruguay; gabriela.velezrubio@gmail.com (G.M.V.-R.); fscarabino@cure.edu.uy (F.S.)

5 Laboratório de Ficologia, Departamento de Botânica, 24 Universidade Federal de Santa Catarina; CEP, Florianópolis, SC 88040-970, Brazil; olgacamacho76@yahoo.com (O.C.);

carolineschmitz-bio@hotmail.com (C.S.)

6 Dirección Nacional de Recursos Acuáticos (DINARA), Montevideo 11200, Uruguay; anamart30@gmail.com (A.M.); leogortega@gmail.com (L.O.); graciela.fabiano@gmail.com (G.F.)

7 Department of Agriculture, Forestry and Fisheries, Private Bag X2 Rogge Bay 8012, South Africa9. Biological Sciences Department and Marine Research Institute, University of Cape Town, Cape Town 7701, South Africa; Mark.Rothman@uct.ac.za

8 Coral Reef Watch, National Oceanic and Atmospheric Administration, College Park, MD 20740, USA; gang.liu@noaa.gov

9 Global Science and Technology, Inc., Greenbelt, MD 20770, USA

10 Laboratorio de Macroalgas Antárticas y Subantárticas, Universidad de Magallanes, Punta Arenas 01855, Chile; jaimeojedavillarroel@yahoo.es (J.O.); andres.mansilla@umag.cl (A.M.)

11 CCMAR - Centre of Marine Sciences, CIMAR, University of Algarve, Campus of Gambelas, 8005-139 Faro, Portugal; luisambarreto74@gmail.com (L.M.B.); jorgemfa@gmail.com (J.A.); eserrao@ualg.pt (E.A.S.); rosantos@ualg.pt (R.S.)

* Correspondence: manuelabiologa@gmail.com; Tel.: +55-48-996-006-101

Received: 8 December 2017; Accepted: 5 February 2018; Published: 13 February 2018

\begin{abstract}
Long-distance dispersal is one of the main drivers structuring the distribution of marine biodiversity. This study reports the first occurrence of Macrocystis pyrifera and Durvillaea antarctica rafts on the southwestern warm temperate coast of the Atlantic Ocean. Our results indicate that an extreme meteo-oceanographic event, characterized by a northward, displacement of cold sub-Antarctic oceanic waters driven by an extratropical cyclone, could account for these unusual occurrences. A niche model based on known current distribution and maximum entropy principle (MAXENT), revealed the availability of suitable habitats at lower latitudes, outside their actual distribution edges. The distributional boundaries, mainly driven by temperature and irradiance, suggest the existence of environmental suitability in warm temperate areas, as well as in the Northern Hemisphere off Atlantic and Asian coasts. These theoretical edges and respective environmental drivers agree with the physiological affinities of both species, supporting the hypothesis that these variables act as limiting factors for their occurrences in tropical or warmer areas. Emerging regions can function as
\end{abstract}


refuges and stepping-stones, providing substrate with adequate habitat conditions for recruitment of propagules, allowing eventual colonization. Long dispersal events reinforce the need for an extensive discussion on selective management of natural dispersion, biological invasions, refuge mapping and conservation initiatives in a transnational perspective.

Keywords: Kelp rafts; marine migration; niche model; biogeography; upwelling; extratropical cyclone

\section{Introduction}

The dispersal of marine organisms is one of the main ecological and evolutionary drivers of marine biodiversity composition and structure, with currents representing one of the principal players in these processes [1-3]. Currents can influence the range of dispersal of migrant populations, promote connectivity, and assist in the process of finding suitable habitats [4-7]. Besides providing transport, currents also play a role in determining niche characteristics, limiting physiological and developmental processes, that require specific abiotic conditions such as temperatures, salinity, and nutrient concentrations [8,9]. Such aspects have been receiving more attention in recent years due to climate change. Global warming is producing critical changes in ocean circulation patterns, niche availability and characteristics, and biodiversity redistribution $[10,11]$. At the same time, changes in global ocean circulation patterns can interact locally with specific regional climatic conditions. In the South Atlantic more frequent and intense storms have been observed in recent decades, which compromise oceanic circulation and migration processes [12-14]. Currents acting together with storm-winds are efficient dispersal mechanisms for floating strategists and associated communities. One such community affected by storms is kelp forests [1,15].

During storms, kelps get detached from the substrate. Many of the detached plants become entangled in other detached kelp plants and eventually form what are called kelp rafts [16]. These floating masses, sometimes abundant and with a diversified fauna and flora, can be transported rapidly and beyond their distributional boundaries $[1,15,16]$. Oceanographic/climatic events can work together to transport an entire specimen, or kelp rafts, with potentially viable propagules, to suitable far-off niches. However, effective species establishment will depend on a combination of abiotic and biotic conditions, which will be influenced by the settlement of the juveniles and the development of the propagules [17-19].

Density dependent mechanisms, such as competition, predation, and herbivory, represent additional dispersal and developmental barriers in marine environments $[1,20,21]$. However, specific benthic organisms or community structure can change micro niche conditions, facilitating settlement and development of invertebrates and primary producers [22,23].

The combination of all these physico-chemical and biological processes will produce the realized niche, which can be recognized as the space currently occupied by a species, after the migratory and selective pressures imposed by positive and negative biological interactions. This is distinct from the fundamental niche $[8,19,24-27]$, where the range of environmental conditions within which a species has a suitable habitat (i.e., can in theory survive and persist), but might not occur there due to biological interactions or processes such as competitive exclusion or limited migration. These concepts were refined by Hutchinson (1957), who hypothesized that the fundamental niche could be mapped in physical space, thus predicting where species should be able to live. The effectiveness of niche modeling tools provides support to Hutchinson's assumptions [28,29]. Nowadays, species distribution models are recognized as an important tool to determine niche suitability for marine organisms, particularly macroalgae, in contemporary climatic and oceanographic spaces [30-33].

Macroalgae play a key role in different marine environments, sometimes building biogenic reefs or underwater forests. These organisms influence and create niches, which represent, food, shelter and substrate for a high diversity of marine organisms, especially in temperate environments [34,35]. 
Kelp forest ecosystems are among the largest biogenic structures found in the benthic marine system [36]. Primary producers were recognized even by ancient naturalists like Charles Darwin, who emphasized the fundamental ecological importance of these subtidal forests in high latitudes of South America [37]. These environments are considered common and abundant in temperate and sub-Antarctic regions [38,39].

One of the dominant species of kelp forests is Macrocystis pyrifera (Linnaeus) C. Agardh, commonly known as giant kelp. It occurs in both the Northern Hemisphere (western coast of North America) and the Southern Hemisphere (i.e., Australia, New Zealand, South Africa, sub-Antarctic islands, and the western and eastern coasts of South America) [31]. In the Southern Atlantic, along the east coast of South America, its northernmost boundary is the northern region of Argentinean Patagonia, Craker Bay $\left(42^{\circ} 56^{\prime} \mathrm{S} 64^{\circ} 27^{\prime}\right.$ W) $[40,41]$. Molecular and fossil characterization indicates that this taxon originates in the North American Pacific Coast, migrating to the Southern Hemisphere 10,000 years ago, during a colder period. Similar North to South migrations have been hypothesized in the Atlantic Ocean [42]. The ancestor of both Laminaria abyssalis A.B. Joly \& E.C. Oliveira and L. pallida Greville, originated in the Northern Hemisphere and migrated south during cold periods.

Kelps have a biphasic life cycle. Ladah \& Zertuche-Gonzales (2007) showed that Macrocystis can survive long periods in its microscopic forms (gametophytes), which would enable it to survive under warmer conditions in a seed bank analogue turf environment. Interestingly, it has been suggested that vegetative propagation of these undifferentiated filamentous haploid forms can have contributed to antitropical east Pacific distribution [43]. Once the conditions become favorable, the gametophytes would continue its life cycle to form the macroscopic thallus (sporophytes) [44]. The sporophytes of Macrocystis pyrifera can grow up to $30 \mathrm{~m}$ in length, on a hard substrate, while it is kept erect in the water column by aerenchyma or floater vesicles, which also facilitate dispersal $[45,46]$. They form large floating patches or "rafts" that can travel long distances for a long period of time (i.e., over three months), with their reproductive capacity still viable [45].

The distribution of Durvillea antarctica (Chamisso) Hariot is limited to the Southern Hemisphere [31,47]. It has a diplontic life cycle. Despite the absence of an alternate phase in the life cycle, this species can remain afloat for more than one month (because of the presence of aerenchyma) in cool water and low irradiance, typical conditions for winter and part of spring or fall. Temperatures of up to $17^{\circ} \mathrm{C}$, combined with higher irradiance during summer (maximal values $16.1-21.8 \mathrm{~W} \mathrm{~m}^{-2}$ ) were correlated with significant biomass losses and rapid destruction of Durvillea rafts [44]. However, some kelp populations have colonized habitats with higher temperatures and irradiances, at lower latitudes, such as those that were observed at the western shores of southern California to Mexico, northern Chile to Peru, south-western South Africa and western Australia [48]. In such cases, despite the relatively lower latitude, environments are influenced by nutrient-rich upwelled waters or cold eastern boundary currents that flow towards the Equator [35,48]. The few kelp species that occur in tropical environments have their distributions restricted to deeper zones within the photic zone, where light and nutrients are sufficient for their growth [31]. Laminaria abyssalis, an endemic to the Brazilian coast, is an example of a tropical kelp. This species occurs at depths of between $40-115 \mathrm{~m}$, and uses rhodolith beds as a substrate [49].

Tropical kelp forests are considered relict species from an immigration of shallow water populations. During the Pleistocene some populations expanded their distributional boundaries to lower latitudes due to the lower Atlantic temperatures, that in these equatorial regions were up to $5{ }^{\circ} \mathrm{C}$ below the mean values observed in the surface during the last decade [50,51]. Presently, climatic projections suggest potential changes in species distribution [52], especially for subtidal kelps, which are vulnerable to sea surface temperature (SST) changes, due to their affinities with cold water [51]. Losses of kelp forests' distributional ranges are reported in various regions of the world [33,53,54]. The reduction of Saccorhiza polyschides (Lightfoot) Batters and Laminaria hyperborea (Gunnerus) Foslie populations on the northern coast of Spain was related to the increase in SST and the reduction of upwelling intensity in the region [54]. However, regional cooling has been observed 
in coastal areas of South America [55] and South Africa [56]. In South Africa, this resulted in the extension of the known distribution limits of Ecklonia maxima (Osbeck) Papenfuss. Some studies suggest that kelp may find refuge in deeper environments, far from the general warming tendency of oceanic surface waters [31,33]. Thus, the existence of temperate algae refuges, even in tropical or warm temperate environments, is of extreme relevance, not only for understanding biogeographic patterns, but for conservation purposes also. Graham et al. (2007) modeled deep-water kelp refugia, and with the use of the model's predictions they have discovered dense and extensive populations of Eisenia galapagensis in deep waters of the Galapagos archipelago. Although modeling constitutes an essential tool for the discussion of marine macroecological processes [57], there are no published articles with models predicting niche habitat suitability for M. pyrifera and D. antarctica, two of the most important kelp species.

Therefore, better understandings of ecological and evolutionary mechanisms would contribute to the comprehension of key population dynamic and resilience. The definition of target foundation species or groups and mapping niche suitability may improve management, when considering future needs for biodiversity management or conservation [58,59]. Differentiating natural drift-refuge colonization process from anthropogenic transport-bioinvasion process is a crucial task [60]. This aspect reinforces discussion about large scale dispersal in an eco-evolutionary framework [61] and should influence stakeholder decision regarding the necessity of conservationist intervention or complete eradication of a migrant target population $[60,61]$.

Here we report (1) the first observation of rafts of two kelp species (M. pyrifera and D. Antarctica) on the Brazilian and Uruguayan coasts; (2) provides the general physiological state of immigrant specimens; (3) discusses the possible origin of these rafts; (4) and model both species habitat suitability considering dispersion routs, potential settlement and colonization on a global scale. Moreover, we characterize the oceanographic processes that caused this dispersal event and discuss implications of these dispersal events considering coastal management and conservation.

\section{Materials and Methods}

\subsection{Study Area}

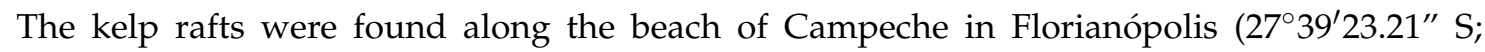
$48^{\circ} 28^{\prime} 13.13^{\prime \prime}$ W), Santa Catarina State, southern Brazil, and the beaches of La Paloma, Punta del Diablo, Santa Teresa, La Coronilla and Barra del Chuy, Uruguay (between $33^{\circ} 38^{\prime} 58.58^{\prime \prime}$ S; $53^{\circ} 27^{\prime} 58.03^{\prime \prime} \mathrm{W}$ and $\left.34^{\circ} 39^{\prime} 52.5^{\prime \prime} \mathrm{S} ; 54^{\circ} 10^{\prime} 0^{\prime \prime} \mathrm{W}\right)$. The continental shelf off this region is located near the Brazil-Malvinas Confluence (BMC) region, located at $38^{\circ} \mathrm{S} \pm 2^{\circ}[59,62]$. The Falkland Current (Malvinas Current) acts as a branch of the sub-Antarctic Front, which is the northernmost oceanographic process associated with the Antarctic Circumpolar Current in the Drake Passage [63]. These cold, sub-Antarctic water masses flow from the south northwards and meet the warmer and more saline waters from the Brazil Current, between latitudes $36^{\circ}$ and $39^{\circ} \mathrm{S}$ giving rise to the Subtropical Convergence [64]. This is also where the South Atlantic Central Water (SACW) current is formed (Figure 1). The nutrient rich, low temperature current intrudes the shallower strata near the continental shelf and is responsible for the common upwelling phenomena, over a $27 \mathrm{~km}$ section of the coast [65], from the southern region of Santa Catarina Island $\left(27^{\circ} 35^{\prime} \mathrm{S}\right)$ to the Cape Santa Marta $\left(28^{\circ} 37^{\prime} \mathrm{S}\right)[62,66]$. During austral winters, this area is influenced by the La Plata river plume, which increases nutrients, and the Sub-Antarctic currents, which reduce the temperatures $[67,68]$.

The southwestern Atlantic biogeographic ecocline described above is also known as the "Arc of Capricorn", representing the southernmost limit of distribution of many tropical organisms [62,69], a warm temperate biogeographic province [70] or general perspective [71]. This region presents a clear seasonal pattern with lowest surface temperatures around $16^{\circ} \mathrm{C}$ observed during winter, and the highest temperatures up to $28^{\circ} \mathrm{C}$ observed during summer [62,72]. However, a more stable colder 
condition is observed in its deeper areas as a consequence of the more frequent influence of the SACW [73].

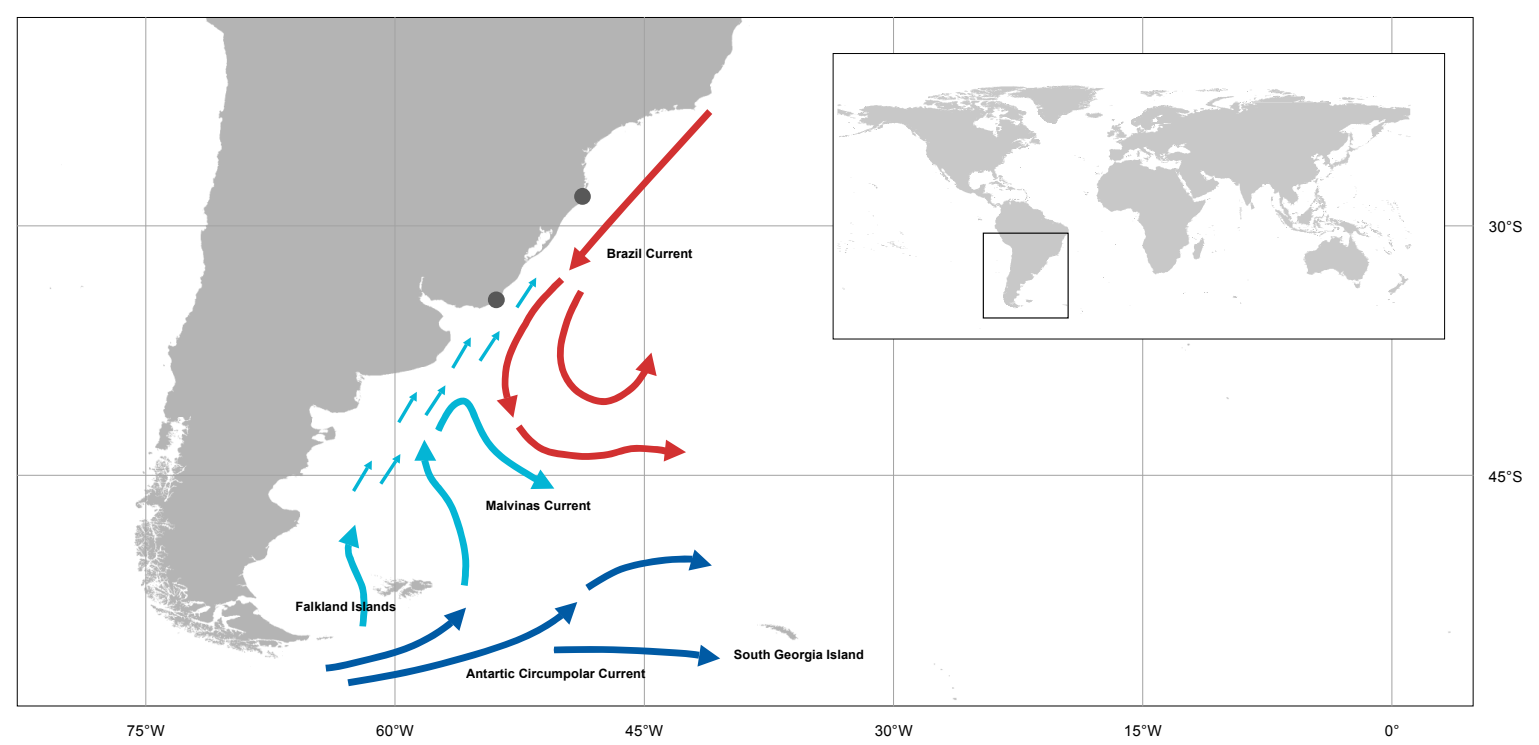

Figure 1. Sampling sites (black points) and main marine currents observed in the drifting region.

\subsection{Collection and Characterization}

The rafted kelp individuals of Macrocystis pyrifera and Durvillaea antarctica were collected on the Uruguayan site between 22 July and 3 August and on the Brazilian site between 26 and 29 September 2016, washed-up on the sand strip and drifting in the region of burst. All the individuals were collected and stored in thermal boxes for transport to the Laboratory of Phycology (Federal University of Santa Catarina, Florianópolis, Santa Catarina, Brazil); due to the massive wash-ups on the Uruguayan coast, only some specimens were collected for transport to the Centro Universitario Regional del Este (CURE, UdelaR, Rocha, Uruguay).

To analyze the physiological conditions, of the washed-up specimens, optimum quantum yield was evaluated in three random benthic Macrocystis specimens. These specimens were from Punta Arenas, Chile (from different periods, to represent periods of before and after the dispersion event), and they were compared to washed-up plants that were collected in Brazil. Thalli were dark acclimated for $15 \mathrm{~min}$ using leaf clips (Diving-LC, Walz) that were placed $\sim 10 \mathrm{~cm}$ from the base of each blade, following procedures applied by Edwards and Kim (2010) with North American populations. Maximum (Fm) and the minimum (Fo) fluorescence, and the PSII optimum quantum yield $(\mathrm{Fv} / \mathrm{Fm})$ were determined for all three specimens. Relative electron transport rates (rETRs) were calculated as $\mathrm{rETR}=\boldsymbol{\Phi}$ PSII $\times$ PPFD; where $\boldsymbol{\Phi}$ PSII is the quantum efficiency of PSII and PPFD is the photosynthetic photon flux density of photosynthetically active radiation (PAR). Rapid light curves (RLCs) were generated using Walz pre-installed routine. Evaluation of $\alpha$, Ek and rETRmax, (where $\alpha=$ photosynthetic efficiency under non-saturating irradiances, Ek = saturation irradiance, and rETRmax = the relative maximum rate of electron transfer to photosystem II under saturation irradiances) was accomplished using Platt et al. (1980) equation. RLCs were not evaluated in the Chilean populations.

Samples of M. pyrifera were identified based on its external morphology [38], while for D. antarctica transverse sections were cut to identify it anatomically [74] (Appendix A). To evaluate the presence of reproductive structures, all morphoanatomical characters, as described by [75], were considered. Fragments from each individual were collected, cleaned and stored in silica gel, for future molecular analyses. Specimens were deposited at the Herbarium FLOR, Federal University of Santa Catarina, Brazil (FLOR 63005, FLOR 63006, FLOR 63007, FLOR 63008, FLOR 63009 and FLOR 630010). 


\subsection{Niche Modeling Procedures}

Macroecological niches of M. pyrifera and D. antarctica were modeled globally using MaxEnt, a robust method, to predict species distributions with presence-only data [76]. This uses the principle of maximum entropy [77], that compares the occurrence records with pseudo-absences generated from background locations, i.e., possible occurrence areas where the presence/absence of species is unknown [78]. The algorithm used in the program was extensively tested in several previous studies $[27,77,79]$ and proved to be a reliable tool to be applied in this context. This method provides a suitable technique, as only data collected from the literature is applied to feed the model [57].

\subsection{Environmental Variables and Occurrence Data}

The environmental variables used to generate niche models were downloaded from Bio-Oracle [29] for the global ocean, under the Behrmann equal-area projection. The selection of variables considered the biology and ecology of kelp forest species (e.g., [80,81]), as well as their degree of collinearity inferred with Variance Inflation Factor (VIF) [82]. Environmental variables with VIF scores above 10 were not considered for modelling purposes [82]. This procedure resulted in 9 variables used as input for models.

Georeferenced occurrence data for the whole distribution of species were compiled from the Australian Virtual Database, Global Biodiversity Information Facility (GBIF, www.gbif.org, accessed on 10 December 2016), and scientific journal articles (Table A1). These data were gridded to the spatial resolution of environmental data, and surplus overlapped entries were discarded to eliminate replication. To further reduce the effect of spatial autocorrelation in the models (see [83], the correlation of environmental variables within the range of occurrence records was determined as a function of geographic distance with Mantel tests under $1 \times 10^{4}$ permutations (e.g., [83]). The records were trimmed by randomly selecting one record only, within the radius of the minimum non-significant $(\alpha=0.05)$ spatially correlated distance. This resulted in 224 records for M. pyrifera and 112 for $D$. antarctica as input for the models (from a total of 889 records originally compiled for M. pyrifera and 616 for D. Antarctica) (Table S1).

To reduce estimation bias introduced by the likely unbalanced distribution of data, background information (i.e., "pseudo-absences") were randomly selected per species from a kernel density estimation surface developed with the occurrence records and a spatial grid conformal in resolution with the environmental data (e.g., $[81,84,85])$. This procedure also restricted the extent of models to the actual distribution of species, a crucial step while modelling ecological niches $[81,86]$.

Over-fitting was controlled by tuning the optimal parameters of models from a range of MaxEnt regularization multipliers (from 0.5 to $5 ; 0.5$ step) and feature classes (i.e., linear, quadratic, hinge, product and threshold) (see [87] for details). A cross-validation framework was implemented in this process to evaluate the performance of models. Statistically independent datasets were produced by partitioning the occurrence records (both presences and pseudo-absences) into 10 distinct latitudinal bands [88]. Models testing different parameters interactively fitted data with one band withheld at a time, where performance was evaluated with the area under the curve (AUC) $[57,89]$ and sensitivity (true positive rate; [89]). Final maps were developed with the combination of parameters retrieving higher average AUC values (identified in cross-validation). These were reclassified to represent suitable/unsuitable areas with the minimum training presence threshold [87,90]. All niche modelling analyses were performed with $\mathrm{R}$ (R Development Core Team, 2017) using the packages dismo, ecospat, parallel, raster and SDMTool.

\subsection{Oceanographic Characterization before and during Dispersion Event}

The Southwest Atlantic surface temperature data, before and during the dispersion event, were obtained from the NOAA database. To evaluate the influence of a specific extreme climate episode on the flux of cold water masses from the South Atlantic towards North, 
we verified the sea surface temperature (SST) from 1 January to 10 October 2016. To exclude the possibility of annual recurrence of the phenomenon, we also verified the flux of water masses during the same period for 2013, 2014 and 2015. SST-anomalies between 2013 and 2016 were evaluated (https://coralreefwatch.noaa.gov/satellite/bleaching $5 \mathrm{~km} /$ index.php). The Group for High-Resolution Sea Surface Temperature (GHRSST) global Level 4 data was obtained from the Physical Oceanography Distributed Active Archive Center (PODAAC), at the NOAA National Centers for Environmental Information, by the satellite AVHRR-ONLY (AVHRR-OI).

\section{Results}

Entire plants of M. pyrifera and D. antarctica were collected at La Paloma, Punta del Diablo, Santa Teresa, La Coronilla and Barra del Chuy, east of Uruguay, on 3 August and successive days. A total of $4 \mathrm{~m}^{3}$ of $M$. pyrifera and $1.3 \mathrm{~m}^{3}$ of D. antarctica were collected from a $2.3 \mathrm{~km}$ stretch of beach at Corumbá beach in La Paloma. During the following month, fragments of both species were collected on Campeche beach, along the eastern portion of Santa Catarina Island, southern Brazil. Algae reached Campeche beach on four consecutive days. We collected a total of $1158 \mathrm{~g}$ of M. pyrifera and $3083 \mathrm{~g}$ of $D$. antarctica, their largest recorded sizes were $180 \mathrm{~cm}$ and $151 \mathrm{~cm}$, respectively (Figure A1). The M. pyrifera rafts that washed-up in Brazil had similar optimum quantum yield variability as compared to plants from natural populations from Chile and North America (Table 1). Reproductive structures were only present in M. pyrifera plants from the Uruguayan rafts but absent in both species from the Brazilian rafts.

Table 1. Comparison of the fluorescence parameters from samples of M. pyrifera from the Brazilian rafts, natural populations from the Chilean plants and from natural populations from the North American plants $\left({ }^{*}=\right.$ Edwards \& Kim 2010; where: Alpha = photosynthetic efficiency; EK = saturated irradiance; rETRmax = relative maximum electron transport rates; and Fv /Fm = maximum quantum yield).

\begin{tabular}{ccccc}
\hline Samples & Alpha & EK & rETRmax & Fv/Fm \\
\hline Rafts & $0.183-0.302$ & $212.54-304.00$ & $50.16-88.07$ & $0.559-0.661$ \\
Chilean population/January & - & - & - & $0.584-0.611$ \\
Chilean population/July & - & - & - & $0.711-0.722$ \\
Chilean population/August & - & - & - & $0.656-0.681$ \\
American Population * & $0.3-0.926$ & $34.4-178.5$ & $14.7-147.4$ & $0.4-0.75$ \\
\hline
\end{tabular}

Figure 2 shows four sea surface temperature (SST) maps, one per year, and an intrusion of colder waters flowing along the Patagonia shelf, following the Malvinas current (MC) towards the southern coast of Brazil. The lower temperatures recorded were approximately $15^{\circ} \mathrm{C}$ in 2013, 2014 and 2015. However, for the same period in 2016, these water masses were colder than compared to 2013, 2014 and 2015, and reached lower latitudes closer to the coast. Figure 2 characterizes a strong advection of cold waters $\left(8-12^{\circ} \mathrm{C}\right)$ from the MC along the Uruguayan and Brazilian shelves. The SST-Anomaly evaluation corroborates previous analyses in the sense that they show a significant inter-annual variability of this cold intrusion.

The SST anomaly, with respect to the long term mean, is presented in Figure 3. In the four maps, warm colors are predominant and this is an indication of the warming of the surface waters of the region. The thermal anomaly along the southernmost third of the South American continental shelf reached $4{ }^{\circ} \mathrm{C}$ in 2016. The cold incursion reaches as far north as the southern tip of the South Brazil Bight (SC, Brazil). Animation of daily maps similar to those in Figure 2 clearly shows the northward evolution of the plume. The continuity of the cold anomaly along the coast shown in Figure 3 for 2016-09 suggests northward advection of MC waters- and its contents. 

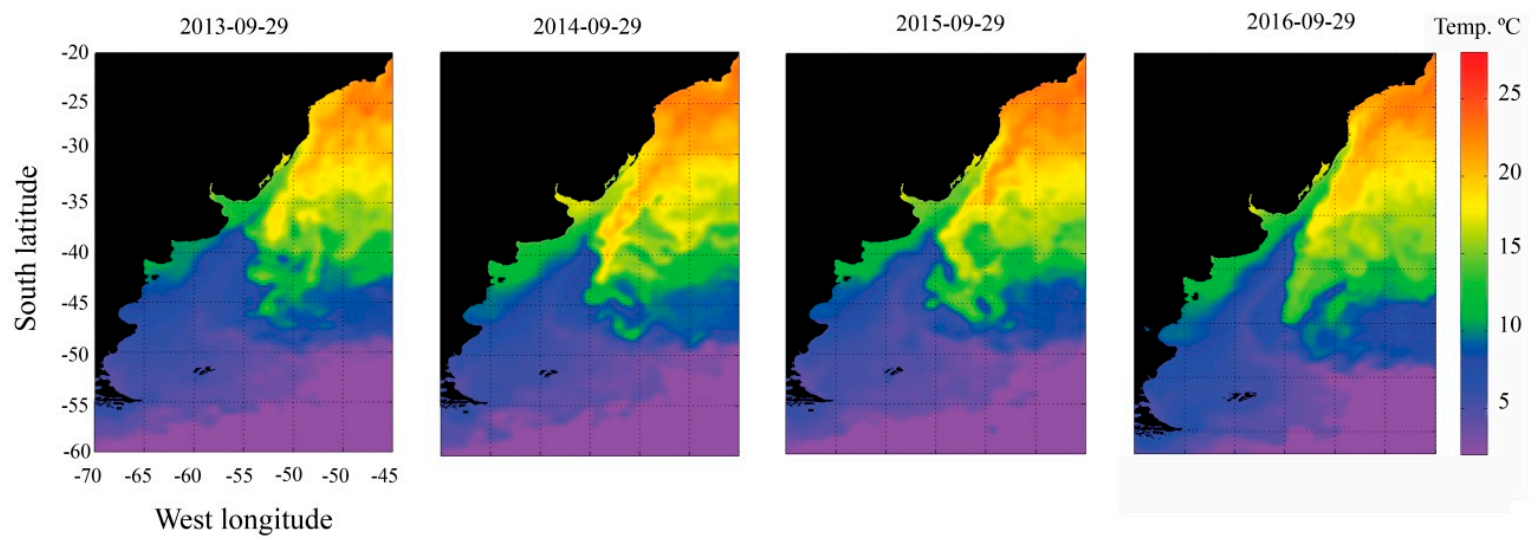

Figure 2. Sea surface temperature (SST) images for locations between $60^{\circ} \mathrm{S}$ to $20^{\circ} \mathrm{S}$ and $45^{\circ} \mathrm{W}$ to $70^{\circ}$ W (29 September) for the years 2013, 2014, 2015 and 2016. The colors indicate differences in SST $\left({ }^{\circ} \mathrm{C}\right)$.

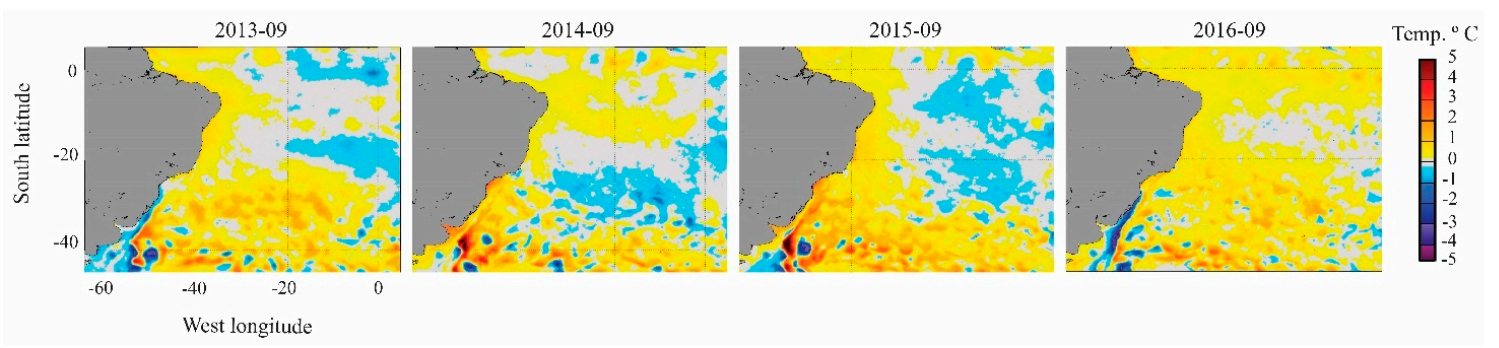

Figure 3. SST anomaly means $\left({ }^{\circ} \mathrm{C}\right)$ images of locations between $40^{\circ} \mathrm{S}$ to $0^{\circ} \mathrm{S}$ and $60^{\circ} \mathrm{W}$ to $0^{\circ} \mathrm{W}$, September, 2013, 2014, 2015 and 2016.

\section{Niche Models at the Global Scale}

The niche models developed for M. pyrifera and D. Antarctica presented a near-perfect prediction, with mean AUC and mean sensitivity scores inferred in cross-validation $>0.9$ and $>0.95$, respectively. The predicted niche suitability in the Southwestern Atlantic Ocean was broader than the known distribution for both species, where the nearest known occurrence distant hundreds of kilometers from the predicted range margin (Figure 4). Among the environmental predictors analyzed, primary productivity (PP), temperatures and phosphates presented the highest contribution to the performance of model for both species. Bottom light also showed to be important restricting vertical distributions, and for M. pyrifera, ice thickness (Figure 5).

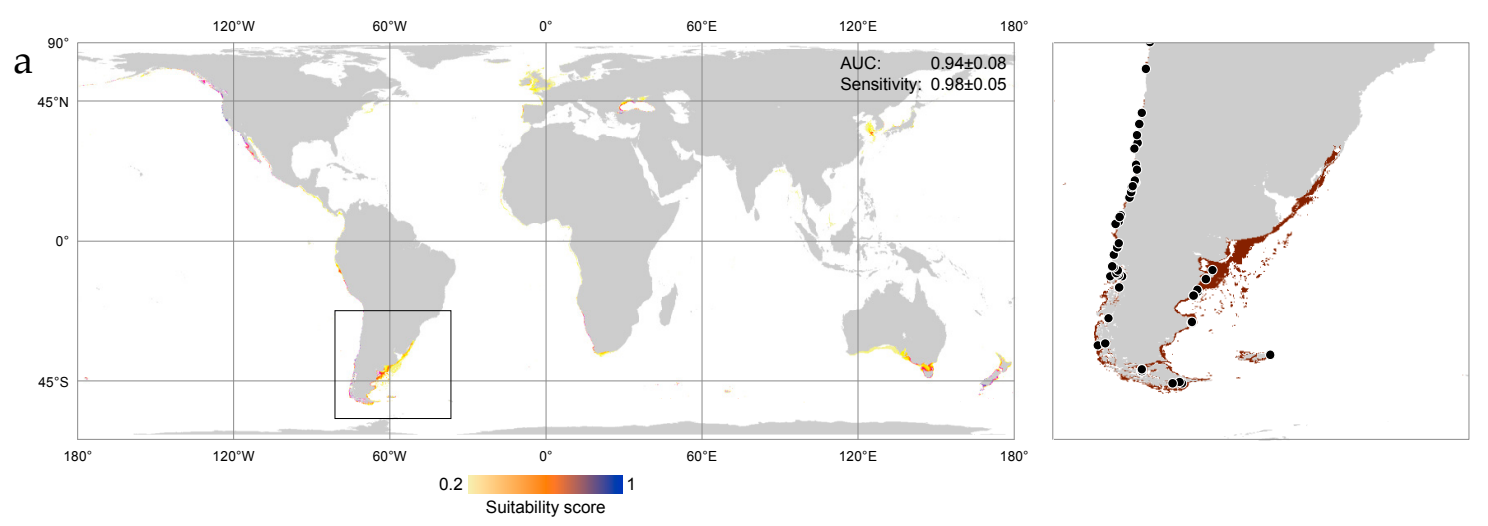

Figure 4. Cont. 


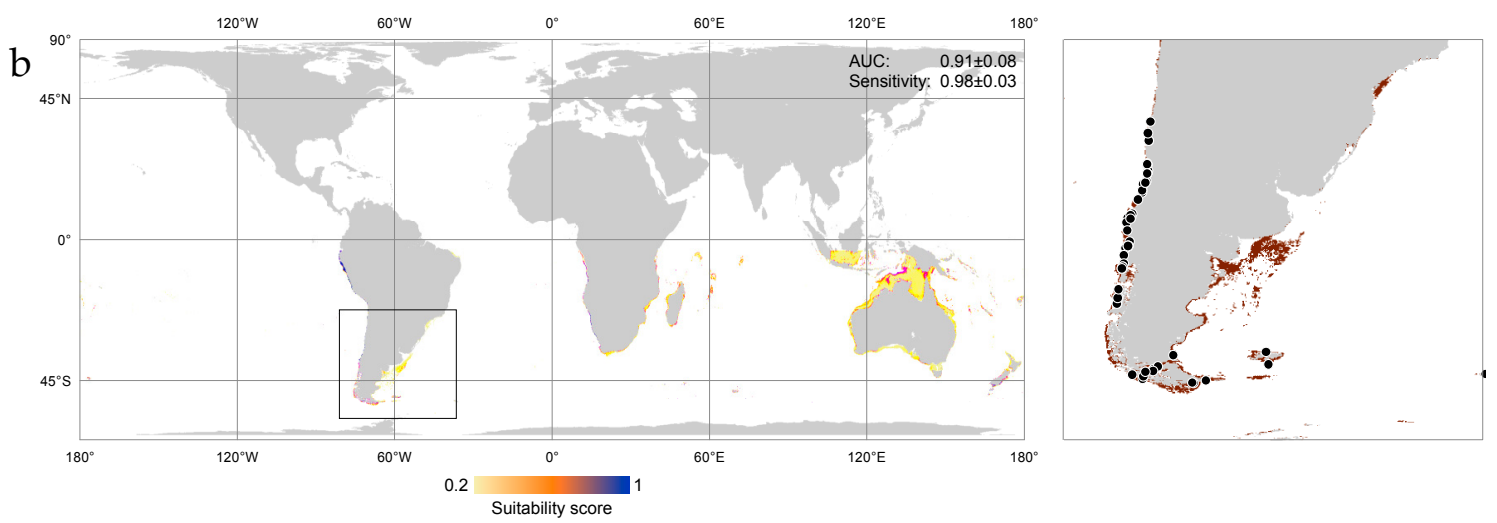

Figure 4. Niche suitability of Macrocystis pyrifera (a) and Durvillaea antarctica (b) predicted in Global coastal areas (left) and with highlight to the Southwestern Atlantic Ocean (high) with maximum entropy (models run globally but predicted to the study region). Points depict known records of occurrence. Mean area under the curve (AUC) and mean sensitivity inferred in cross-validation also shown.

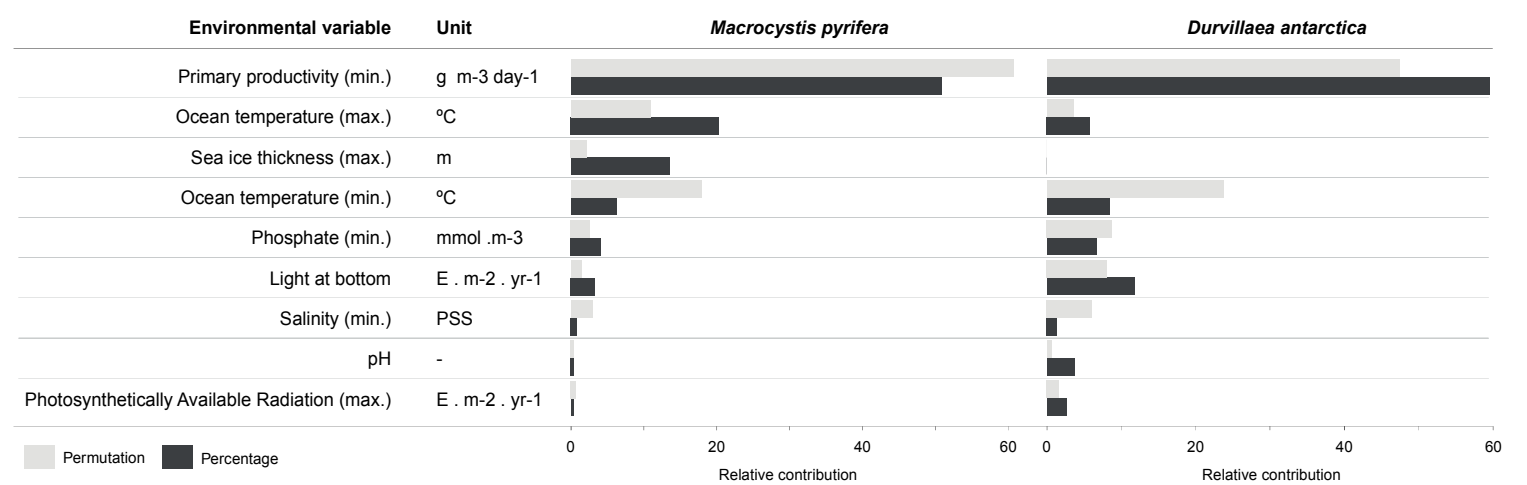

Figure 5. Relative contributions of the environmental variables to the models developed for Macrocystis pyrifera and Durvillaea antarctica, as percentage contribution and permutation importance.

\section{Discussion}

The arrival of M. pyrifera and D. antarctica on the Uruguay and southwestern coast of Brazil represented an intriguing phenomenon that has impressed researchers in physiology and even algae experts around the world (B.M.B. personal communication). The potential origin of these kelp rafts is more than $2000 \mathrm{~km}$ away, because the most likely and nearest well-documented occurrence, of both species, is the Falkland Islands [91]. The washed up plants, observed on the Uruguayan and Brazilian coasts showed that they have the physiological tools to acclimatize to the floating conditions in this area, during this period [92]. Despite a long drift process, the oceanographic and climatic conditions (cold water and reduced winter irradiance), observed during the end of the 2016 winter, could be responsible for the good physiological health of the M. pyrifera and D. antarctica rafts that washed up in Brazil [93]. Mature sporophylls from the Macrocystis rafts that washed up in Uruguay revealed the mechanism that promote connectivity among populations in the Southern Hemisphere and represent a source for colonization of the mapped suitable niches. The niche suitability, which was detected in all the regions that are subject to the Antarctic Circumpolar current, corroborated statements that indicated high connectivity among southern populations. Suitable temperature, irradiance and nutrient conditions, especially during the summer, enabled long-distance dispersion at this latitudinal range, as was hypothesized by Tala et al. [87] and reinforced here by our modeling evaluation.

It is essential to recognize that these species are known for their ability to travel long distances due to morphological structures, such as aerocysts, which provide buoyancy $[39,45,94,95]$. Studies involving passive dispersion of these species recorded distances of tens of kilometers [46,96]. Our data 
indicate that M. pyrifera and D. antarctica potentially traveled a distance of at least $2700 \mathrm{~km}$, reaching the Brazilian coast, still alive. Such evidence confirms that Macrocystis can grow and keep its reproductive viability while drifting for long periods at latitudes around $27^{\circ} \mathrm{S}$ during winter [92]. This high immigration capacity was shown by our physiological data, which demonstrated that raft chlorophyll a fluorescence descriptors were similar to the sessile Chilean and North American populations [97]. An experiment by Hernández-Carmona et al. [46] showed M. pyrifera still had viable zoospores after being adrift for 125 days and drifting for a distance of $890 \mathrm{~km}$. This ability is sufficient to connect populations throughout a hemisphere, on a generational time scale, and may even facilitate gene flow between hemispheres under specific meteo-oceanographic conditions.

The floating specimens were found along the Brazilian coast during the last week of September 2016 (late Austral winter), approximately 13 days after the registration of a polar mesocyclone that reached the Argentinean, Uruguayan and Southern Brazilian coasts (Figure 6). Winds of up to $130 \mathrm{~km} / \mathrm{h}$ were recorded in the coastal region of these countries and a sea level variation of up to $8 \mathrm{~m}$ high was recorded in Mar del Plata, Argentina (NOAA 2016). Considering the magnitude of this event and the relationship between extreme events and erosion of kelp forest structure, it is plausible that this storm produced the rafts and promoted the dispersal event. Storms and strong-wind events, such as extratropical cyclones, can detach canopy-forming kelps, transporting the rafts and immigrants, facilitating long-distance dispersal and transport of their propagules to suitable niches [25]. Furthermore, these storm and strong wind conditions can provide a pick-up/drop off process, and enhance the along-shelf current towards lower latitudes. This period of ideal conditions, with low temperatures and an enhanced northward current is observed at the end of Winter and late Spring in this region $[98,99]$.
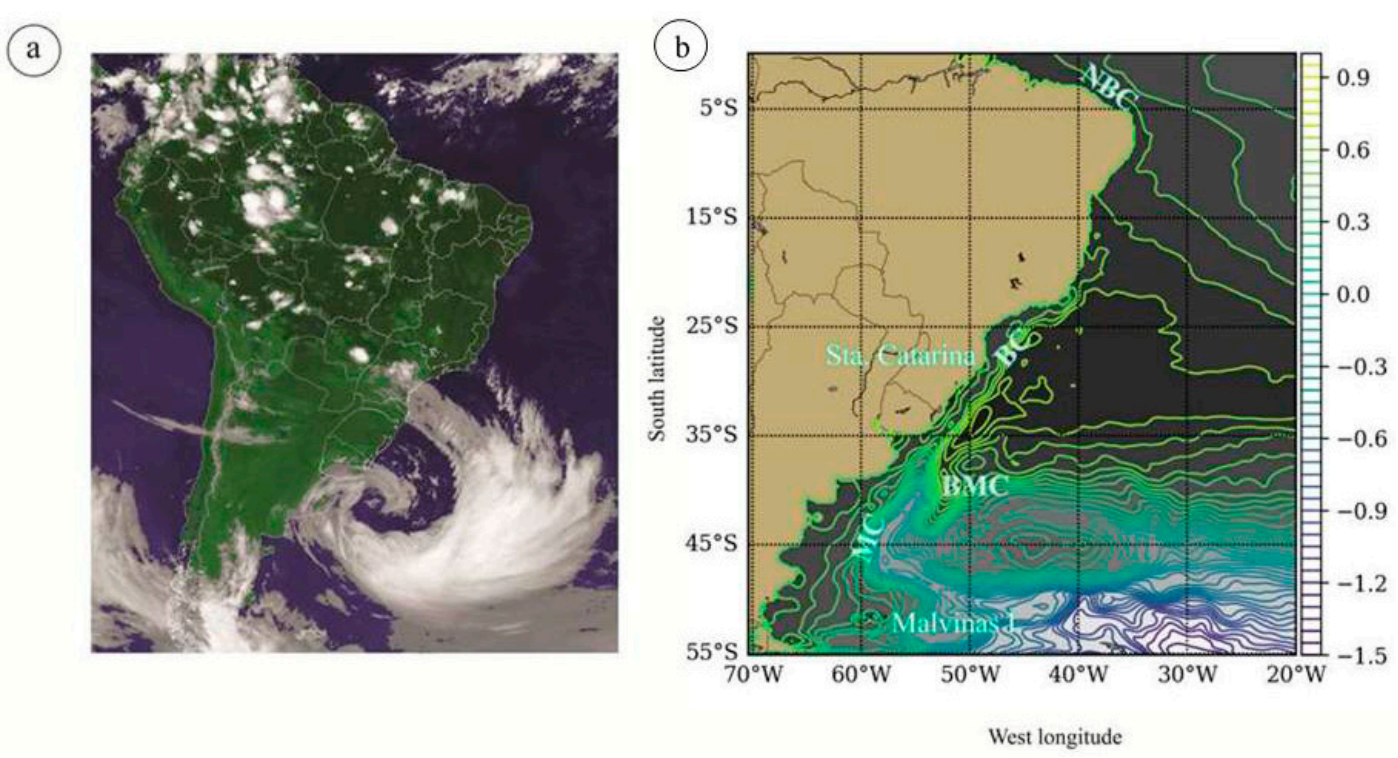

Figure 6. (a) Images of the cyclone recorded on 13 September 2016, captured by the satellite GOES-16 (NOAA); (b) Confluence region (BMC) the Brazil (BC)-Malvinas Currents (MC) (Falklands). The colored lines are dynamic temporal mean of the dynamic height, taken between 1993 and 2013. They represent the major geostrophic current systems such as the BC, MC and NBC (North Brazilian Current). In this sense, currents flow parallel to the contours, with higher contours (yellow) on the left height. The intensity of the current is inversely proportional to the spacing between lines. (MDT_CNES-CLS13 was produced by CLS Space Oceanography Division and distributed by Aviso, with support from Cnes (http:/ / www.aviso.altimetry.fr/).

The CBM has an annual latitudinal dynamic, oscillating to the north during the Austral summer and to the south during the Austral winter [63]. Such variations can be attributed to the large scale 
variability in the atmospheric forcing, mostly winds of the southern quadrant originating from the Austral Winter [63]. There is an intensification of the Malvinas Current (CM), which carries Sub Antarctic waters and brings energy to smaller latitudes of the Southern Atlantic [100]. Such patterns can be verified in the SST satellite images of 2013, 2014 and 2015, the three years preceding the event (Figure 2). Therefore, the intrusion of cold waters on the southwestern coast of Brazil can be considered a common phenomenon during the Austral winter. However, in 2016, SST maps (Figure 2) showed that, in addition to this cold-water intrusion, that reached lower latitudes, there were intrusions of approximately $8{ }^{\circ} \mathrm{C}$ as well as one of approximately $12{ }^{\circ} \mathrm{C}$. During the same period, and in the same region, surface temperature anomalies were captured by the GOES-16 satellite (Figure 3).

Considering the floating and rafting nature of these species, they probably reached the coast of Brazil driven by strong extratropical cyclone winds, and changes in the velocity and SST on the surface coastal currents [64]. Moreover, the plume of the La Plata River $\left(35^{\circ} 58^{\prime} \mathrm{S} ; 55^{\circ} 18^{\prime} \mathrm{W}\right)$ along with the south-northward coastal circulation, may have contributed to the dispersal of the individuals of D. antarctica and M. pyrifera to the coastal region of southwestern Brazil. Nutrient enrichment from rivers and upwelling feed the high demand of kelp species for nitrogen and phosphate [93], helping in the resilience of rafts during the long drift.

The destination of floating algae, in medium and lower latitudes, is mainly determined by the combination of abiotic and biotic factors (e.g., temperature currents, irradiation, and suitable habitats) [45,101,102]. Rothäusler et al. (2011) showed that floating Macrocystis, at mid-latitudes, $\left(25^{\circ} \mathrm{S}-40^{\circ} \mathrm{S}\right)$ have a higher physiological adaptability and consequent ability to float for long periods of time, and over long distances, surviving at temperatures ranging between $12{ }^{\circ} \mathrm{C}$ and $20^{\circ} \mathrm{C}$ [45]. Experimentally they also showed that $M$. pyrifera could not withstand temperatures higher than $24^{\circ} \mathrm{C}$, and specimens perished after 5 days. Nevertheless, in northern Baja California M. pyrifera populations are exposed to SST variations of between $12.7^{\circ} \mathrm{C}$ to $22.5^{\circ} \mathrm{C}$, while the southernmost subtropical populations show warmer temperature tolerances varying between $15.6{ }^{\circ} \mathrm{C}$ to $25.5{ }^{\circ} \mathrm{C}$ [103]. It is already well established that climate changes can affect substantially species distribution and, more particularly, alter the rafts' trajectory, which will influence the dispersal and distribution of marine organisms $[46,96,104]$. Therefore, this aspect should be considered with particular attention.

Along the Brazilian coast, the algae were washed up at the beach and drifted in the breakwater zone, which does not allow one to confirm whether these species inhabited the region. However, the near-perfect prediction, indicating that at the spatial scale of our study, the environmental variables used, explained the actual species distributions, and pose the discussion regarding distribution extension [57]. The main predictors which influenced the models were variables related to PP, temperature and, nutrient availability and light. Due to the physiological requirements and affinities of the species known for low temperatures [45], we can confirm that maximum SST and bottom light were the limiting factors for latitudinal and vertical distribution. Such a conclusion is evident when we observe the georeferenced distribution of species restricted to environments in high and medium latitudes in shallow areas, where the temperature and radiation were lower. The partial dependency function shows that primary PP limits the distribution of Macrocystis and Durvillaea on its very low levels, commonly observed in lower latitudes and deeper ocean regions. PP combines in a single predictor the resource availability, involving irradiance, $\mathrm{CO}_{2}$, temperatures and nutrients [105]. This shows the negative effect of oligotrophic regions and positive effect that upwelling and medium latitudes regions have globally (e.g., [105]). The model (Figures 4 and 5) reinforces the sensitivity of these species to changes in temperature, radiation and water quality (i.e., especially turbidity), because these are the factors that delimit their geographical distribution [31,36]. However, it points towards probable refuge regions, interestingly, in lower latitudes, far from regions previously recognized with "optimum" environmental conditions, extrapolating their suitable habitats also to other temperate regions in the Northern Hemisphere. The regional cooling of coastal environments observed in the southwestern Atlantic warm temperate province southern edge [55,65] corroborate the niche suitability described for the south of Brazil and Uruguay. The range extension of the South African kelp, 
Ecklonia maxima, was also ascribed to a regional cooling process [56]. Therefore, kelps are ecosystem engineers, responsible for most of the primary production where they occur. This would mean that the spread or dispersal of kelps could have ecological, economical and sociological consequences.

In addition, it is likely that the ideal habitats for these species are located at deeper strata of the region. Studies report that some kelp species move to deeper water in a response to warming trends $[33,106,107]$. Species occurring in the tropics with high temperate affinities tend to occupy deeper niches [31], as is the case of Laminaria abyssalis, the only kelp-forming species ever recorded on the Brazilian coast [49]. Laminaria abyssalis is endemic to the Brazilian coast and has a specific biotope. It occurs on rhodolith beds $\left(21^{\circ} \mathrm{S}\right.$ and $\left.40^{\circ} \mathrm{W}\right)$ at depths between 40 to $120 \mathrm{~m}$, at temperatures of between $15-19^{\circ} \mathrm{C}$, and at low light intensity $[108,109]$. Due to the influence of SACW, deeper waters in southern Brazil are colder and is less variable when compared to surface [73] conditions, most of the time, optimal or tolerated for both kelp species.

Therefore, it is important to note that environmental variables used in the model are collected from the ocean surface. Considering deeper environments in the continental platform, it would be reasonable to assume that the probability of finding suitable habitats for these species would be even greater. Many suitable deeper refuges for these species can be identified, such as the Rio Grande rocky parcels at Rio Grande Sul State, southern Brazil, or Vitória Trindade seamounts, Espírito Santo State, southwestern Brazil. In these environments the topography of the seamounts can promote the upwelling of the cold nutrient rich waters, cooling and fertilizing the warmer, oligotrophic shallow waters [110], and in turn provide potentially ecophysiological conditions for the development of kelp spores or germlings [93]. We reinforce that the apparent absence of both species in areas with high habitat suitability is probably a consequence of absence or scarcity of sampling efforts. Therefore, suitability maps can be utilized in the definition of target areas for further surveys regarding kelp presence and kelp forest composition, diversity and connectivity.

However, populations of M. pyrifera may be limited not only by physical factors such as temperature, light and nutrients, but also by the type of substrate and the presence of herbivores (e.g., sea urchin species such as Loxechinus albus) [36]. Due to a lack of available herbivore data, on a global scale, among other important biological interactions, these biotic factors were not considered in our evaluations.

The introduction of benthic macroalgae is a frequent phenomenon in coastal regions $[41,111]$. Recently, the occurrence of Grateloupia turuturu Yamada was documented in the south-western Atlantic, more specifically on the coast of the state of Santa Catarina, in Brazil [112]. Despite its high potential as an invasive algae species in the world, G. turuturu has a higher affinity for temperate environments [112]. The species, which was first detected in the Southwestern Atlantic in 2011, can easily be found on the rocky shores near the point where the washed-up kelp rafts were found.

The effects of the arrival of kelp species such as M. pyrifera and D. antarctica in a new ern pacific populations have varied, over hundreds of kilometers along the Baja Califunexpected environment is still not documented, although the southern limit of the northeastornia peninsula, during the past 20 years [113]. Migration is a fundamental process to increase resilience of populations, a natural part of an eco-evolutionary framework [61], where selective pressure variability meet phenotypic plasticity of the respective immigrant population. Therefore, if they are part of a natural dynamic equilibrium of marine environments these events should be better understood and preserved. Alternatively, if anthropogenic vectors promote it, these events must be evaluated under the usual bioinvasion perspective, and the management of this process should consider eradication. The kelp Undaria pinnatifida, also a canopy-forming kelp, is rated as the fifth most successful invasive species in the world $[41,114]$. However, studies have shown that where $U$. pinnatifida invaded there was no evidence of interspecific competition, except for small effects on the abundance of some species of intertidal communities $[41,115]$. Therefore, healthy forests of fucoids tend to resist invasions, unless the canopy is disturbed $[116,117]$. So far, there are no records on the effects of kelp-forming algae invading regions where no large algae forests occur. 
The niche model results reinforce the need for transnational discussions regarding habitats, considered refuges for conservation initiatives in a global context of climate change intensification [118,119]. Such an environmental change could produce meteo-oceanographic events which could displace large amount of kelp rafts over long distances. In addition to these events, ocean acidification could cause disturbances in underwater autochthone communities, producing opportunities for kelp immigration that could change the resilience of eventual host communities [120]. Considering the importance of these organisms to coastal ecology (e.g., carbon fixation from the atmosphere, increasing habitat complexity and diversity) [31,121], these questions should be discussed at international forums and monitoring programs should be planned to consider possible origins and dispersal routes. These discussions should influence planning and the design, size and position of marine protected areas (MPA) that should add as potential services the preservation of species with this ability to survive long periods drifting.

\section{Conclusions}

The occurrence of these kelp rafts in the Brazilian and Uruguayan coast does not characterize the expansion of their limits of occurrence because settled populations were not found. However, such events could be regarded as an indication of change in climatic/oceanographic processes. Our results indicate that viable rafts can travel long distances, which demand a further discussion about long-term management of these immigration events. Therefore, changes in current temperatures and patterns may alter kelps raft routes and potential colonization areas. Considering the remarkable role that these rafts play in facilitating the dispersal and connectivity between coastal faunal and floristic communities, events such as this require greater attention regarding invasive species monitoring programs, niche conservation policies and climatic changes.

Supplementary Materials: The following are available online at www.mdpi.com/1424-2818/10/1/11/s1, Table S1: Georeferenced Occurrences Macrocystis pyrifera and Durvillaea antartica used to generate the model and video S1: Images of sea surface temperature (SST) for locations between $60^{\circ} \mathrm{S}$ at $20^{\circ} \mathrm{S}$ and $45^{\circ} \mathrm{W}$ at $70^{\circ} \mathrm{W}$ between the months of January and September 2016.

Acknowledgments: Conselho Nacional de Desenvolvimento Científico e Tecnológico (CNPq 306917/2009-2 to P.A. Horta) and Coordenação de Aperfeiçoamento de Pessoal de Nível Superior (CAPES/PNPD 02828/09-0 and CAPES/PNADB 2338000071/2010-61 to P.A. Horta), Polito: CNPQ Universal 447109/2014-6, Instituto Nacional de Ciência e Tecnologia para Mudanças Climáticas (INCT-MC), ProspecMar-Islands-Sustainable prospecting in Ocean Islands: Biodiversity, Chemistry, Ecology and Biotechnology, Boticário Foundation (1051-20152), Rede Coral Vivo and REDEALGAS, Brazilian Research Network on Global Climate Change and FAPESC-Foundation support research and innovation in the State of Santa Catarina. We thank the Portuguese Fundação para a Ciência e Tecnologia (FCT) for SFRH/BPD/111003/2015 (JA) and PTDC/MAR-EST/6053/2014 (EAS).

Author Contributions: Conceived and wrote the paper: M.B.B. and P.A.H.; detected and collected species: A.B.A., G.V.-R., F.S., A.M., L.O., G.F.; extracted data from Web of Science: C.S., J.A. and M.B.B.; analyzed the data: P.F.S, P.S.P., T.C.L.S., A.B.A. and M.B.B.; contributed with data: G.L., J.O., A.M.; critical revision and discussions: P.A.H., O.C., M.D.R., L.B., J.A., E.A.S. and R.S.

Conflicts of Interest: The authors declare no conflict of interest. 


\section{Appendix A}
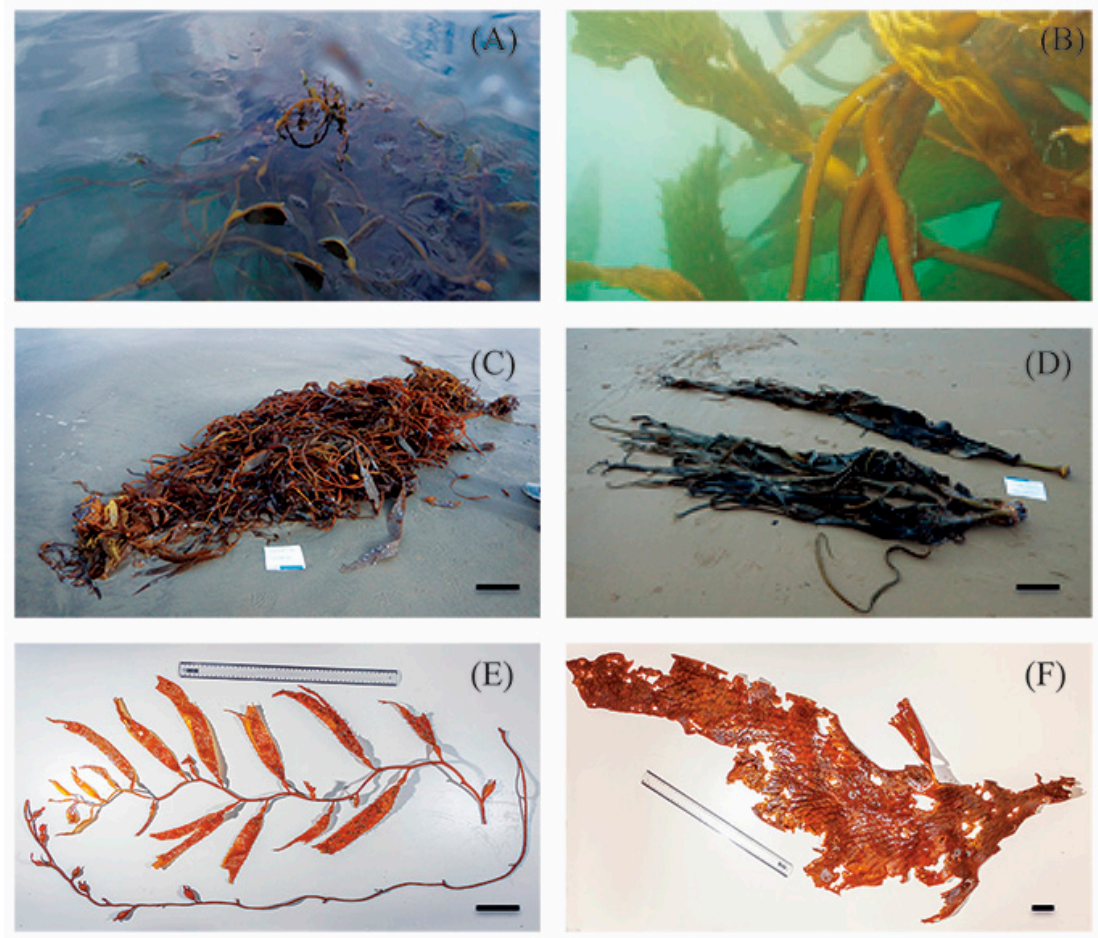

Figure A1. Macrocystis pyrifera (A-C) and Durvillaea antarctica (D) on the Uruguayan beach and their respectives fragments $(\mathbf{E}, \mathbf{F})$ that arrived in south of Brazil collected at Campeche Beach, south of Brazil (scales: $\mathrm{C}=15 \mathrm{~cm} ; \mathrm{D}=30 \mathrm{~cm}, \mathrm{E}=10 \mathrm{~cm}, \mathrm{~F}=10 \mathrm{~cm}$ ).
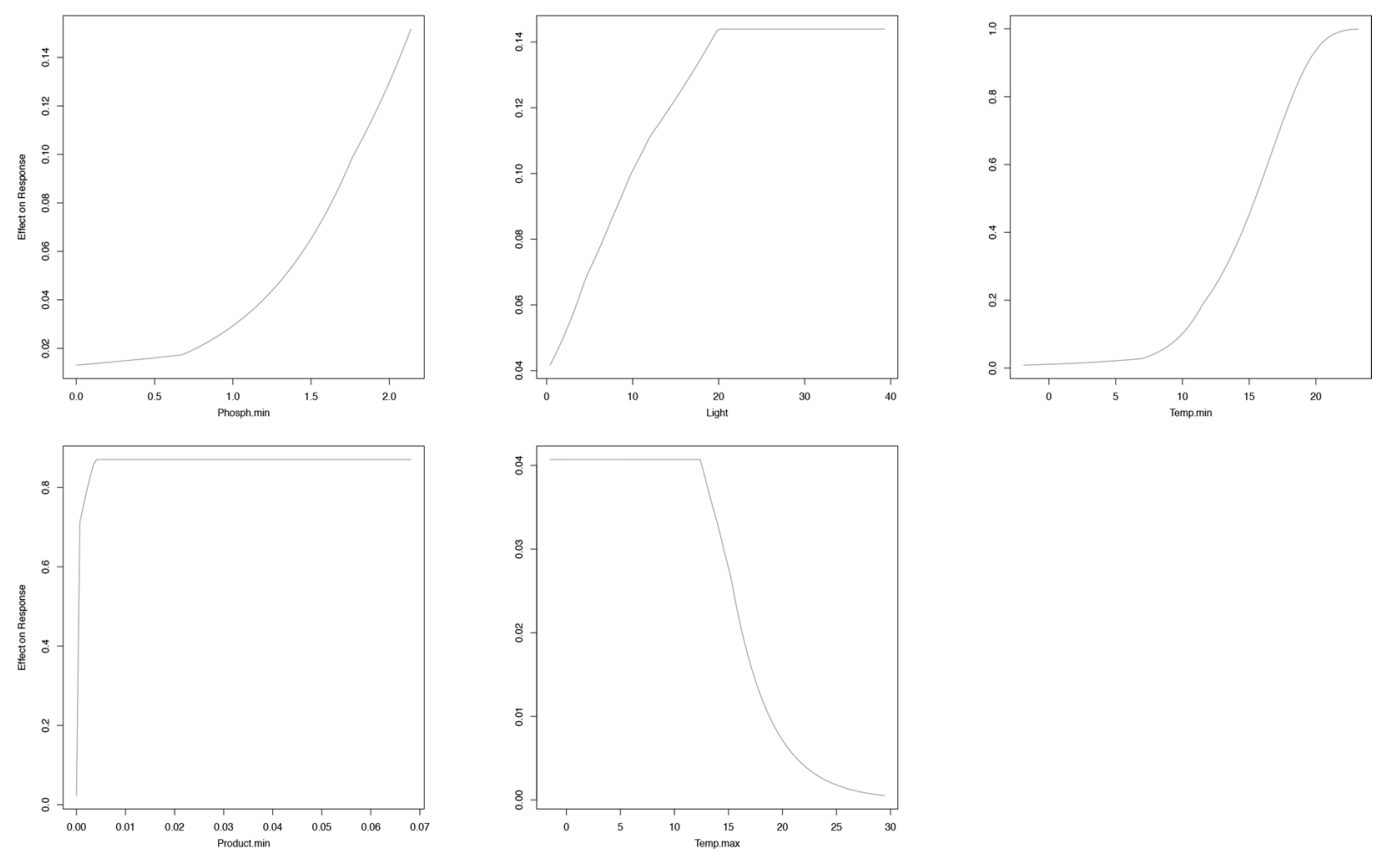

Figure A2. Durvillaea antarctica parcial plots. 

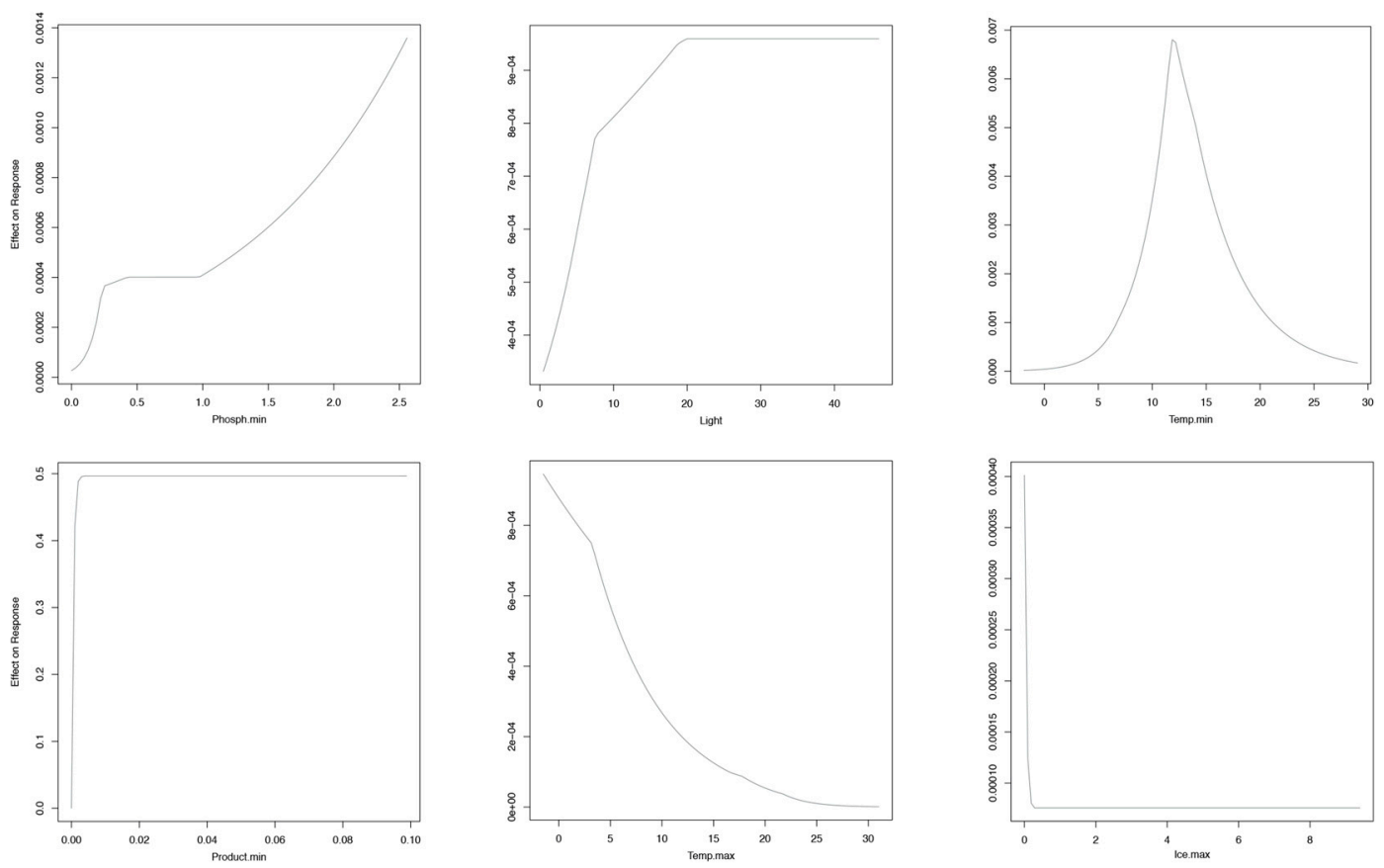

Figure A3. Macrocystis pyrifera parcial plots. 


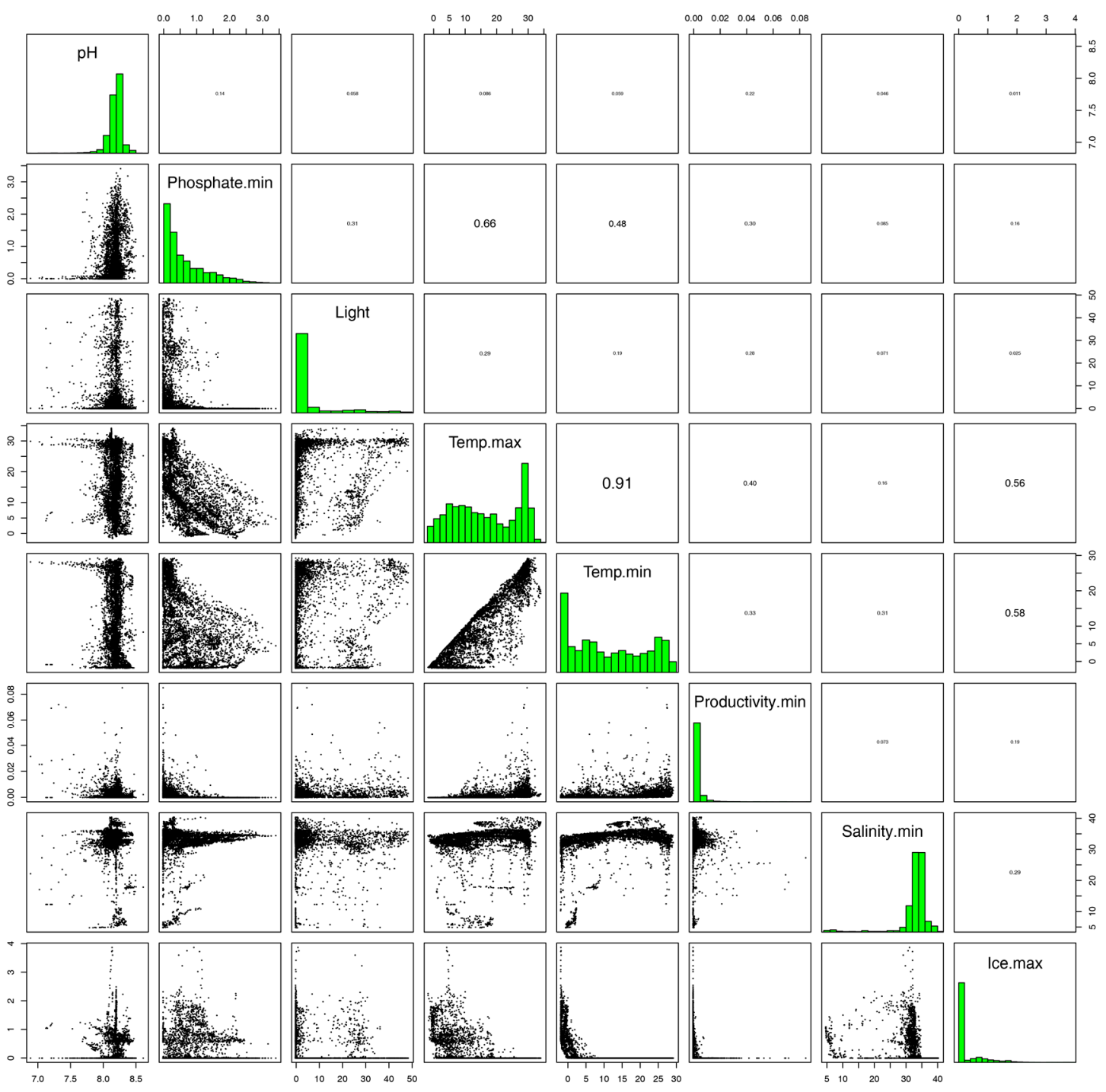

Figure A4. Pairs plots.

Table A1. Scientific articles used to obtain records of occurrence of the species Macrocystis pyrifera (A) and Durvillaea antarctica (B).

\begin{tabular}{cl}
\hline Species & \multicolumn{1}{c}{ Citation } \\
\hline A & $\begin{array}{l}\text { Barrales, H.L.; Lobban, C.S. The comparative ecology of Macrocystis pyrifera, with emphasis on the } \\
\text { forests of Chubut, Argentina. The Journal of Ecology 1975, 657-677. }\end{array}$ \\
\hline A & Dayton, P. Kelp communities of southern south America. Antarct J US 1974. \\
\hline A & $\begin{array}{l}\text { Zimmerman, R.C.; Kremer, J.N. In situ growth and chemical composition of the giant kelp, } \\
\text { Macrocystis pyrifera: Response to temporal changes in ambient nutrient availability. Marine Ecology } \\
\text { Progress Series 1986, 277-285. }\end{array}$ \\
\hline A & $\begin{array}{l}\text { Macaya, E.C.; Zuccarello, G.C. Genetic structure of the giant kelp em Macrocystis pyrifera along the } \\
\text { southeastern pacific. Marine Ecology Progress Series 2010, 420, 103-112. }\end{array}$ \\
A & $\begin{array}{l}\text { Beas-Luna, R.; Ladah Lydia, B. Latitudinal, seasonal, and small-scale spatial differences of the giant } \\
\text { kelp, Macrocystis pyrifera, and an herbivore at their southern range limit in the northern hemisphere. } \\
\text { In Botanica Marina, 2014; Vol. 57, p. 73. }\end{array}$ \\
A & $\begin{array}{l}\text { Johansson, M.L.; Alberto, F.; Reed, D.C.; Raimondi, P.T.; Coelho, N.C.; Young, M.A.; Drake, P.T.; } \\
\text { Edwards, C.A.; Cavanaugh, K.; Assis, J. Seascape drivers of Macrocystis pyrifera population genetic } \\
\text { structure in the northeast pacific. Molecular Ecology 2015, 24, 4866-4885. }\end{array}$ \\
\hline
\end{tabular}


Table A1. Cont.

\begin{tabular}{|c|c|}
\hline Species & Citation \\
\hline A & $\begin{array}{l}\text { Riosmena-Rodríguez, R.; Boo, G.H.; López-Vivas, J.M.; Hernández-Velasco, A.; Sáenz-Arroyo, A.; } \\
\text { Boo, S.M. The invasive seaweed Sargassum filicinum (Fucales, Phaeophyceae) is on the move along } \\
\text { the Mexican pacific coastline. Botanica Marina } \mathbf{2 0 1 2 , 5 5 , 5 4 7 - 5 5 1 .}\end{array}$ \\
\hline A & $\begin{array}{l}\text { Starko, S.; Martone, P.T. Evidence of an evolutionary-developmental trade-off between drag } \\
\text { avoidance and tolerance strategies in wave-swept intertidal kelps (Laminariales, Phaeophyceae). } \\
\text { Journal of Phycology 2016, 52, 54-63. }\end{array}$ \\
\hline A & $\begin{array}{l}\text { Ladah Lydia, B.; Zertuche-González José, A. Giant kelp (Macrocystis pyrifera) survival in deep water } \\
(25-40 \text { m) during el Niño of 1997-1998 in Baja California, Mexico. In Botanica Marina, 2004; Vol. 47, } \\
\text { p. } 367 .\end{array}$ \\
\hline A & $\begin{array}{l}\text { Asensi, A.O.; Küpper, F.C. Seasonal periodicity and reproduction of brown algae (Phaeophyceae) at } \\
\text { Puerto Deseado (Patagonia). Botanica Marina 2012, 55, 217-228. }\end{array}$ \\
\hline A & $\begin{array}{l}\text { Cazón, J.P.; Viera, M.; Sala, S.; Donati, E. Biochemical characterization of Macrocystis pyrifera and } \\
\text { Undaria pinnatifida (Phaeophyceae) in relation to their potentiality as biosorbents. Phycologia 2014, 53, } \\
\text { 100-108. }\end{array}$ \\
\hline A & $\begin{array}{l}\text { Macaya, E.C.; Boltaña, S.; Hinojosa, I.A.; Macchiavello, J.E.; Valdivia, N.A.; Vásquez, N.R.; } \\
\text { Buschmann, A.H.; Vásquez, J.A.; Alonso Vega, J.M.; Thiel, M. Presence of sporophylls in floating } \\
\text { kelp rafts of Macrocystis spp. (Phaeophyceae) along the Chilean pacific coast. Journal of Phycology } \\
\text { 2005, 41,913-922. }\end{array}$ \\
\hline A & $\begin{array}{l}\text { Engel, C.R.; Billard, M.V., Emmanuelle; Viard, F. Conservation and polymorphism of mitochondrial } \\
\text { intergenic sequences in brown algae (Phaeophyceae). European Journal of Phycology 2008, 43, 195-205. }\end{array}$ \\
\hline A & $\begin{array}{l}\text { Rothäusler, E.; Gómez, I.; Karsten, U.; Tala, F.; Thiel, M. Physiological acclimation of floating } \\
\text { Macrocystis pyrifera to temperature and irradiance ensures long-term persistence at the sea surface at } \\
\text { mid-latitudes. Journal of Experimental Marine Biology and Ecology 2011, 405, 33-41. }\end{array}$ \\
\hline A & $\begin{array}{l}\text { Van Tussenbroek, B. Plant and frond dynamics of the giant kelp, Macrocysti spyrifera, forming a } \\
\text { fringing zone in the Falkland Islands. European Journal of Phycology 1993,28,161-165. }\end{array}$ \\
\hline A & $\begin{array}{l}\text { Hurd, C.L.; Pilditch, C.A. Flow-induced morphological variations affect diffusion boundary-layer } \\
\text { thickness of Macrocystis pyrifera (Heterokontophyta, Laminariales). Journal of Phycology 2011, 47, } \\
\text { 341-351. }\end{array}$ \\
\hline A & $\begin{array}{l}\text { Ricker, R.W. Taxonomy and biogeography of Macquarie Island seaweeds. British Museum (Natural } \\
\text { History): } 1987 .\end{array}$ \\
\hline A & $\begin{array}{l}\text { John, D.M.; Pugh, P.J.; Tittley, I. Observations on the benthic marine algal flora of South Georgia: } \\
\text { A floristic and ecological analysis. Bulletin of the Natural History Museum. Botany Series } \mathbf{1 9 9 4 .}\end{array}$ \\
\hline A & $\begin{array}{l}\text { Hay, C.H. A new species of Macrocystisc. Ag. (Phaeophyta) from Marion Island, Southern Indian } \\
\text { ocean. Phycologia 1986, 25, 241-252. }\end{array}$ \\
\hline B & $\begin{array}{l}\text { Boraso, A.; Zaixso, J. Atlas de sensibilidad ambiental de la costa y el mar argentino. Algas marinas } \\
\text { bentónicas 2011, 1-28. }\end{array}$ \\
\hline B & $\begin{array}{l}\text { Boraso, A.L. Elementos para el estudio de las macroalgas de argentina. Comodoro Rivadavia: Editorial } \\
\text { Universitaria de la Patagonia EDUPA } \mathbf{2 0 1 3 .}\end{array}$ \\
\hline B & $\begin{array}{l}\text { Graiff, A.; Karsten, U.; Meyer, S.; Pfender, D.; Tala, F.; Thiel, M. Seasonal variation in floating } \\
\text { persistence of detached Durvillaea antarctica (chamisso) hariot thalli. Botanica Marina 2013, 56, 3-14. }\end{array}$ \\
\hline B & $\begin{array}{l}\text { López, B.A.; Macaya, E.C.; Tala, F.; Tellier, F.; Thiel, M. The variable routes of rafting: Stranding } \\
\text { dynamics of floating bull kelp Durvillaea antarctica (Fucales, Phaeophyceae) on beaches in the se } \\
\text { pacific. Journal of Phycology 2017, 53,70-84. }\end{array}$ \\
\hline B & $\begin{array}{l}\text { Cho, G.Y.; Rousseau, F.; De Reviers, B.; Boo, S.M. Phylogenetic relationships within the Fucales } \\
\text { (Phaeophyceae) assessed by the photosystem i coding psa a sequences. Phycologia 2006, 45, 512-519. }\end{array}$ \\
\hline B & $\begin{array}{l}\text { Fraser, C.I.; Hay, C.H.; Spencer, H.G.; Waters, J.M. Genetic and morphological analyses of the } \\
\text { southern bull kelp Durvillaea antarctica (Phaeophyceae: Durvillaeales) in new Zealand reveal cryptic } \\
\text { species. Journal of Phycology 2009, 45, 436-443. }\end{array}$ \\
\hline B & $\begin{array}{l}\text { Wells, E.; Brewin, P.; Brickle, P. Intertidal and subtidal benthic seaweed diversity of South Georgia. } \\
\text { Norfolk, UK } 2011 .\end{array}$ \\
\hline
\end{tabular}


Table A1. Cont.

\begin{tabular}{|c|c|}
\hline Species & Citation \\
\hline B & $\begin{array}{l}\text { Ortiz, J.; Romero, N.; Robert, P.; Araya, J.; Lopez-Hernandez, J.; Bozzo, C.; Navarrete, E.; Osorio, A.; } \\
\text { Rios, A. Dietary fiber, amino acid, fatty acid and tocopherol contents of the edible seaweeds Ulva } \\
\text { lactuca and Durvillaea antarctica. Food Chemistry 2006, 99, 98-104. }\end{array}$ \\
\hline B & $\begin{array}{l}\text { Bustamante, R.; Castilla, J. Impact of human exploitation on populations of the intertidal southern } \\
\text { bull-kelp Durvillaea antarctica (Phaeophyta, Durvilleales) in central Chile. Biological Conservation } \\
\text { 1990, 52, 205-220. }\end{array}$ \\
\hline B & $\begin{array}{l}\text { Smith, S.; Simpson, R. Effects of the 'nella dan' oil spill on the fauna of Durvillaea antarctica holdfasts. } \\
\text { Marine Ecology Progress Series 1995, 73-89. }\end{array}$ \\
\hline B & $\begin{array}{l}\text { Collins, C.J.; Fraser, C.I.; Ashcroft, A.; Waters, J.M. Asymmetric dispersal of southern bull-kelp } \\
\text { (Durvillaea antarctica) adults in coastal New Zealand: Testing an oceanographic hypothesis. } \\
\text { Molecular Ecology 2010, 19, 4572-4580. }\end{array}$ \\
\hline B & $\begin{array}{l}\text { Smith, J.; Bayliss-Smith, T. Kelp-plucking: Coastal erosion facilitated by bull-kelp Durvillaea } \\
\text { antarctica at subantarctic Macquarie Island. Antarctic Science 1998, 10, 431-438. }\end{array}$ \\
\hline B & $\begin{array}{l}\text { Dillehay, T.D.; Ramirez, C.; Pino, M.; Collins, M.B.; Rossen, J.; Pino-Navarro, J. Monte verde: } \\
\text { Seaweed, food, medicine, and the peopling of South America. Science 2008, 320, 784-786. }\end{array}$ \\
\hline B & $\begin{array}{l}\text { Taylor, D.I.; Schiel, D.R. Self-replacement and community modification by the southern bull kelp } \\
\text { Durvillaea antarctica. Marine Ecology Progress Series 2005, 288, 87-102. }\end{array}$ \\
\hline B & $\begin{array}{l}\text { Chancho, M.J.R.; Sánchez, J.F.L.; Rubio, R. Occurrence of arsenic species in the seagrass Posidonia } \\
\text { oceanica and in the marine algae Lessonia nigrescens and Durvillaea antarctica. Journal of Applied } \\
\text { Phycology 2010, 22, 465-472. }\end{array}$ \\
\hline B & $\begin{array}{l}\text { Castilla, J.; Campo, M.; Bustamante, R. Recovery of Durvillaea antarctica (durvilleales) inside and } \\
\text { outside las cruces marine reserve, Chile. Ecological Applications 2007, 17, 1511-1522. }\end{array}$ \\
\hline B & Smith, S.D. Kelp rafts in the Southern Ocean. Global Ecology and Biogeography 2002, 11, 67-69. \\
\hline B & $\begin{array}{l}\text { Matsuhiro, B.; Zúñiga, E.; Jashes, M.; Guacucano, M. Sulfated polysaccharides from Durvillaea } \\
\text { antarctica. Hydrobiologia 1996, 321, 77-81. }\end{array}$ \\
\hline B & $\begin{array}{l}\text { Kelly, B.J.; Brown, M.T. Variations in the alginate content and composition of Durvillaea antarctica } \\
\text { and D. willana from southern New Zealand. Journal of Applied Phycology 2000, 12,317-324. }\end{array}$ \\
\hline B & $\begin{array}{l}\text { Collantes, G.; Merino, A.; Lagos, V. Fenología de la gametogénesis, madurez de conceptáculos, } \\
\text { fertilidad y embriogénesis en Durvillaea antarctica (chamisso) Hariot (Phaeophyta, Durvillaeales). } \\
\text { Revista de Biología Marina y Oceanografía 2002, 37, 83-112. }\end{array}$ \\
\hline B & $\begin{array}{l}\text { Tala, F.; Gómez, I.; Luna-Jorquera, G.; Thiel, M. Morphological, physiological and reproductive } \\
\text { conditions of rafting bull kelp (Durvillaea antarctica) in northern-central Chile ( } 30 \text { s). Marine Biology } \\
\text { 2013, 160, 1339-1351. }\end{array}$ \\
\hline B & $\begin{array}{l}\text { Castilla, J.C.; Defeo, O. Latin American benthic shellfisheries: Emphasis on co-management and } \\
\text { experimental practices. Reviews in Fish Biology and Fisheries 2001,11,1-30. }\end{array}$ \\
\hline B & $\begin{array}{l}\text { Nikula, R.; Fraser, C.I.; Spencer, H.G.; Waters, J.M. Circumpolar dispersal by rafting in two } \\
\text { subantarctic kelp-dwelling crustaceans. Marine Ecology Progress Series 2010, 405, 221-230. }\end{array}$ \\
\hline B & $\begin{array}{l}\text { Stevens, C.L.; Hurd, C.L.; Smith, M.J. An idealized model of interaction between fronds of the large } \\
\text { seaweed Durvillaea antarctica. Journal of Marine Systems 2004, 49, 145-156. }\end{array}$ \\
\hline B & $\begin{array}{l}\text { Goecke, F.; Wiese, J.; Núñez, A.; Labes, A.; Imhoff, J.F.; Neuhauser, S. A novel phytomyxean parasite } \\
\text { associated with galls on the bull-kelp Durvillaea antarctica (Chamisso) Hariot. PLoS ONE 2012, 7, } \\
\text { e45358. }\end{array}$ \\
\hline B & $\begin{array}{l}\text { Castilla, J.C.; Manríquez, P.H.; Camaño, A. Effects of rocky shore coseismic uplift and the } 2010 \\
\text { Chilean mega-earthquake on intertidal biomarker species. Marine Ecology Progress Series 2010, 418, } \\
\text { 17-23. }\end{array}$ \\
\hline B & $\begin{array}{l}\text { Miller, I.J. Alginate composition of some New Zealand brown seaweeds. Phytochemistry 1996, 41, } \\
\text { 1315-1317. }\end{array}$ \\
\hline B & $\begin{array}{l}\text { Fraser, C.I.; Kay, G.M.; Plessis, M.d.; Ryan, P.G. Breaking down the barrier: Dispersal across the } \\
\text { Antarctic Polar Front. Ecography 2017, 40, 235-237. }\end{array}$ \\
\hline
\end{tabular}


Table A1. Cont.

\begin{tabular}{|c|c|}
\hline Species & Citation \\
\hline B & $\begin{array}{l}\text { Duarte, C.; Acuña, K.; Navarro, J.M.; Gómez, I. Intra-plant differences in seaweed nutritional quality } \\
\text { and chemical defenses: Importance for the feeding behavior of the intertidal amphipod Orchestoidea } \\
\text { tuberculata. Journal of Sea Research 2011, 66, 215-221. }\end{array}$ \\
\hline B & $\begin{array}{l}\text { Astorga-España, M.S.; Mansilla, A. Sub-antarctic macroalgae: Opportunities for gastronomic } \\
\text { tourism and local fisheries in the region of Magallanes and Chilean Antarctic territory. Journal of } \\
\text { Applied Phycology 2014, 26, 973-978. }\end{array}$ \\
\hline B & $\begin{array}{l}\text { Beckley, L.E.; Branch, G.M. A quantitative scuba-diving survey of the sublittoral macrobenthos at } \\
\text { subantarctic Marion Island. Polar Biology 1992, 11, 553-563. }\end{array}$ \\
\hline B & $\begin{array}{l}\text { Bussolini, L.T.; Waters, J.M. Genetic analyses of rafted macroalgae reveal regional oceanographic } \\
\text { connectivity patterns. Journal of Biogeography } 2015,42,1319-1326 .\end{array}$ \\
\hline B & $\begin{array}{l}\text { Cruces, E.; Huovinen, P.; Gomez, I. Phlorotannin and antioxidant responses upon short-term } \\
\text { exposure to uv radiation and elevated temperature in three south pacific kelps. Photochemistry and } \\
\text { Photobiology 2012, 88, 58-66. }\end{array}$ \\
\hline B & $\begin{array}{l}\text { Díaz, O.; Tapia, Y.; Muñoz, O.; Montoro, R.; Velez, D.; Almela, C. Total and inorganic arsenic } \\
\text { concentrations in different species of economically important algae harvested from coastal zones of } \\
\text { Chile. Food and Chemical Toxicology 2012, 50,744-749. }\end{array}$ \\
\hline B & $\begin{array}{l}\text { Dimartino, S.; Savory, D.M.; Fraser-Miller, S.J.; Gordon, K.C.; McQuillan, A.J. Microscopic and } \\
\text { infrared spectroscopic comparison of the underwater adhesives produced by germlings of the } \\
\text { brown seaweed species Durvillaea antarctica and Hormosira banksii. Journal of The Royal Society } \\
\text { Interface 2016, 13, 2015-1083. }\end{array}$ \\
\hline B & $\begin{array}{l}\text { Dufour, C.; Probert, P.; Savage, C. Macrofaunal colonisation of stranded Durvillaea antarctica on a } \\
\text { southern New Zealand exposed sandy beach. New Zealand Journal of Marine and Freshwater Research } \\
\mathbf{2 0 1 2}, 46,369-383 \text {. }\end{array}$ \\
\hline B & $\begin{array}{l}\text { Fraser, C.I.; Nikula, R.; Waters, J.M. Oceanic rafting by a coastal community. Proceedings of the Royal } \\
\text { Society of London B: Biological Sciences 2011, 278, 649-655. }\end{array}$ \\
\hline B & $\begin{array}{l}\text { González, A.V.; Beltrán, J.; Flores, V.; Santelices, B. Morphological convergence in the inter-holdfast } \\
\text { coalescence process among kelp and kelp-like seaweeds (Lessonia, Macrocystis, Durvillaea). Phycologia } \\
\mathbf{2 0 1 5}, 54,283-291 \text {. }\end{array}$ \\
\hline B & $\begin{array}{l}\text { Garden, C.J.; Smith, A.M. The role of kelp in sediment transport: Observations from southeast New } \\
\text { Zealand. Marine Geology 2011, 281, 35-42. }\end{array}$ \\
\hline B & $\begin{array}{l}\text { Haye, P.A.; Varela, A.I.; Thiel, M. Genetic signatures of rafting dispersal in algal-dwelling brooders } \\
\text { Limnoria spp. (isopoda) along the se Pacific (Chile). Marine Ecology Progress Series 2012, 455, 111-122. }\end{array}$ \\
\hline B & $\begin{array}{l}\text { Hinojosa, I.; González, E.; Ugalde, P.; Valdivia, N.; Macaya, E.; Thiel, M. Distribución y abundancia } \\
\text { de macroalgas flotando a la deriva y su fauna peracarida asociada en los canales de la xl región, } \\
\text { Chile. Ciencia y Tecnología del Mar 2007, } 30 .\end{array}$ \\
\hline B & $\begin{array}{l}\text { Huovinen, P.; Leal, P.; Gómez, I. Interacting effects of copper, nitrogen and ultraviolet radiation on } \\
\text { the physiology of three south pacific kelps. Marine and Freshwater Research 2010, 61, 330-341. }\end{array}$ \\
\hline B & $\begin{array}{l}\text { Fraser, C.I.; Thiel, M.; Spencer, H.G.; Waters, J.M. Contemporary habitat discontinuity and historic } \\
\text { glacial ice drive genetic divergence in Chilean kelp. BMC Evolutionary Biology 2010, 10, } 203 .\end{array}$ \\
\hline B & $\begin{array}{l}\text { Jaramillo, E.; De la Huz, R.; Duarte, C.; Contreras, H. Algal wrack deposits and macroinfaunal } \\
\text { arthropods on sandy beaches of the Chilean coast. Revista Chilena de Historia Natural 2006, } 79 .\end{array}$ \\
\hline B & $\begin{array}{l}\text { Lizée-Prynne, D.; López, B.; Tala, F.; Thiel, M. No sex-related dispersal limitation in a dioecious, } \\
\text { oceanic long-distance traveller: The bull kelp durvillaea antarctica. In Botanica Marina, 2016; Vol. 59, } \\
\text { p. } 39 .\end{array}$ \\
\hline B & $\begin{array}{l}\text { Miranda, L.; Thiel, M. Active and passive migration in boring isopods Limnoria spp. (Crustacea, } \\
\text { Peracarida) from kelp holdfasts. Journal of Sea Research } \mathbf{2 0 0 8 , 6 0 , 1 7 6 - 1 8 3 .}\end{array}$ \\
\hline B & $\begin{array}{l}\text { Nikula, R.; Spencer, H.; Waters, J. Evolutionary consequences of microhabitat: Population-genetic } \\
\text { structuring in kelp-vs. Rock-associated chitons. Molecular Ecology 2011, 20, 4915-4924. }\end{array}$ \\
\hline B & $\begin{array}{l}\text { Smith, S.D.A. The effects of a small sewage outfall on an algal epifaunal community at Macquarie } \\
\text { Island (sub-antarctic): A drop in the southern ocean? Marine Pollution Bulletin 2000, 40, 873-878. }\end{array}$ \\
\hline
\end{tabular}


Table A1. Cont.

\begin{tabular}{|c|c|}
\hline Species & Citation \\
\hline B & $\begin{array}{l}\text { Smith, J.; Summers, G.; Wong, R. Nutrient and heavy metal content of edible seaweeds in New } \\
\text { Zealand. New Zealand Journal of Crop and Horticultural Science 2010, 38, 19-28. }\end{array}$ \\
\hline B & $\begin{array}{l}\text { Taylor, D.I.; Schiel, D.R. Wave-related mortality in zygotes of habitat-forming algae from different } \\
\text { exposures in southern New Zealand: The importance of 'stickability'. Journal of Experimental Marine } \\
\text { Biology and Ecology 2003, 290, 229-245. }\end{array}$ \\
\hline B & $\begin{array}{l}\text { Alestra, T.; Schiel, D. Impacts of local and global stressors in intertidal habitats: Influence of altered } \\
\text { nutrient, sediment and temperature levels on the early life history of three habitat-forming } \\
\text { macroalgae. Journal of Experimental Marine Biology and Ecology 2015, 468, 29-36. }\end{array}$ \\
\hline B & $\begin{array}{l}\text { Anderson, M.J.; Diebel, C.E.; Blom, W.M.; Landers, T.J. Consistency and variation in kelp holdfast } \\
\text { assemblages: Spatial patterns of biodiversity for the major phyla at different taxonomic resolutions. } \\
\text { Journal of Experimental Marine Biology and Ecology 2005, 320,35-56. }\end{array}$ \\
\hline B & $\begin{array}{l}\text { Collantes, G.; Riveros, R.; Acevedo, M. (fenologia reproductiva de Durvillaea antarctica (Phaeophyta, } \\
\text { Durvillaeales) del intermareal de caleta Montemar, Chile Central). Oceanographic Literature Revieww } \\
\text { 1998, } 8,1412 \text {. }\end{array}$ \\
\hline B & $\begin{array}{l}\text { De Souza, B.W.S.; Teixeira, D.I.A.; Andrade, F.K.; Melo, M.R.S.; Muñoz, A.M.; Freitas, A.L.P. } \\
\text { A survey of Antarctic algae for agglutinins. Oecologia Australis 2009, 11, 122-130. }\end{array}$ \\
\hline B & $\begin{array}{l}\text { Eriksson, C.; Burton, H.; Fitch, S.; Schulz, M.; van den Hoff, J. Daily accumulation rates of marine } \\
\text { debris on sub-antarctic island beaches. Marine Pollution Bulletin 2013, 66, 199-208. }\end{array}$ \\
\hline B & $\begin{array}{l}\text { Tait, L.W.; South, P.M.; Lilley, S.A.; Thomsen, M.S.; Schiel, D.R. Assemblage and understory carbon } \\
\text { production of native and invasive canopy-forming macroalgae. Journal of Experimental Marine } \\
\text { Biology and Ecology 2015, 469, 10-17. }\end{array}$ \\
\hline B & $\begin{array}{l}\text { Tala, F.; Velásquez, M.; Mansilla, A.; Macaya, E.C.; Thiel, M. Latitudinal and seasonal effects on } \\
\text { short-term acclimation of floating kelp species from the south-east pacific. Journal of Experimental } \\
\text { Marine Biology and Ecology 2016, 483, 31-41. }\end{array}$ \\
\hline B & $\begin{array}{l}\text { Aguilera, M.A.; Valdivia, N.; Broitman, B.R. Herbivore-alga interaction strength influences spatial } \\
\text { heterogeneity in a kelp-dominated intertidal community. PloS one 2015, 10, e0137287. }\end{array}$ \\
\hline B & $\begin{array}{l}\text { Astorga-España, M.S.; Mansilla, A.; Ojeda, J.; Marambio, J.; Rosenfeld, S.; Mendez, F.; Rodriguez, J.; } \\
\text { Ocaranza, P. Nutritional properties of dishes prepared with sub-antarctic macroalgae an } \\
\text { opportunity for healthy eating. Journal of Applied Phycology 2017, 1-8. }\end{array}$ \\
\hline B & $\begin{array}{l}\text { Mansilla, A.O.; Avila, M.; Cáceres, J. Reproductive biology of Durvillaea antarctica (Chamisso) Hariot } \\
\text { in the sub-antartic ecoregion of Magallanes }\left(51-56^{\circ} \text { s). Journal of Applied Phycology 2017, 1-8. }\right.\end{array}$ \\
\hline
\end{tabular}

\section{References}

1. MacArthur, R.H.; Wilson, E.O. Theory of Island Biogeography (MPB-1); Princeton University Press: Princeton, NJ, USA, 2015; Volume 1, p. 216.

2. Jackson, S.T.; Sax, D.F. Balancing biodiversity in a changing environment: Extinction debt, immigration credit and species turnover. Trends Ecol. Evol. 2010, 25, 153-160. [CrossRef] [PubMed]

3. Pinheiro, H.T.; Bernardi, G.; Simon, T.; Joyeux, J.-C.; Macieira, R.M.; Gasparini, J.L.; Rocha, C.; Rocha, L.A. Island biogeography of marine organisms. Nature 2017, 549, 82-85. [CrossRef] [PubMed]

4. Mackas, D.L.; Denman, K.L.; Abbott, M.R. Plankton patchiness: Biology in the physical vernacular. Bull. Mar. Sci. 1985, 37, 652-674.

5. Gilg, M.R.; Hilbish, T.J. The geography of marine larval dispersal: Coupling genetics with fine-scale physical oceanography. Ecology 2003, 84, 2989-2998. [CrossRef]

6. Zakas, C.; Binford, J.; Navarrete, S.A.; Wares, J.P. Restricted gene flow in Chilean barnacles reflects an oceanographic and biogeographic transition zone. Mar. Ecol. Prog. Ser. 2009, 394, 165-177. [CrossRef]

7. Gaylord, B.; Gaines, S.D. Temperature or transport? Range limits in marine species mediated solely by flow. Am. Nat. 2000, 155, 769-789. [CrossRef] [PubMed]

8. Brown, J.H. Macroecology; University of Chicago Press: Chicago, IL, USA, 1995; p. 284.

9. Brown, J.H.; Maurer, B.A. Macroecology: The division of food and space among species on continents. Science 1989, 243, 1145-1150. [CrossRef] [PubMed] 
10. Beal, L.M.; De Ruijter, W.P.M.; Biastoch, A.; Zahn, R. On the role of the agulhas system in ocean circulation and climate. Nature 2011, 472, 429-436. [CrossRef] [PubMed]

11. O'Gorman, E.J. It's only a matter of time: The altered role of subsidies in a warming world. J. Anim. Ecol. 2016, 85, 1133-1135. [CrossRef] [PubMed]

12. Sissini, M.N.; Oliveira, M.C.; Gabrielson, P.W.; Robinson, N.M.; Okolodkov, Y.B.; Riosmena-Rodríguez, R.; Horta, P.A. Mesophyllum erubescens (corallinales, rhodophyta)-so many species in one epithet. Phytotaxa 2014, 190, 299-319. [CrossRef]

13. Knutson, T.R.; McBride, J.L.; Chan, J.; Emanuel, K.; Holland, G.; Landsea, C.; Held, I.; Kossin, J.P.; Srivastava, A.K.; Sugi, M. Tropical cyclones and climate change. Nat. Geosci. 2010, 3, 157-163. [CrossRef]

14. Coumou, D.; Rahmstorf, S. A decade of weather extremes. Nat. Clim. Chang. 2012, 2, 491-496. [CrossRef]

15. Easterling, D.R.; Meehl, G.A.; Parmesan, C.; Changnon, S.A.; Karl, T.R.; Mearns, L.O. Climate extremes: Observations, modeling, and impacts. Science 2000, 289, 2068-2074. [CrossRef] [PubMed]

16. Chen, I.-C.; Hill, J.K.; Ohlemüller, R.; Roy, D.B.; Thomas, C.D. Rapid range shifts of species associated with high levels of climate warming. Science 2011, 333, 1024-1026. [CrossRef] [PubMed]

17. Pearson, R.G.; Dawson, T.P. Predicting the impacts of climate change on the distribution of species: Are bioclimate envelope models useful? Glob. Ecol. Biogeogr. 2003, 12, 361-371. [CrossRef]

18. Anderson, A.B.; Salas, E.M.; Rocha, L.A.; Floeter, S.R. The recent colonization of south brazil by the azores chromis chromis limbata. J. Fish Biol. 2017, 91, 558-573. [CrossRef] [PubMed]

19. Tegner, M.J.; Dayton, P.K.; Edwards, P.B.; Riser, K.L. Large-scale, low-frequency oceanographic effects on kelp forest succession: A tale of two cohorts. Mar. Ecol. Prog. Ser. 1997, 146, 117-134. [CrossRef]

20. Garbary, D.J. Biogeography of marine algae. In eLS; John Wiley \& Sons, Ltd.: Hoboken, NJ, USA, 2001; pp. 1-9.

21. Soberón, J.; Nakamura, M. Niches and distributional areas: Concepts, methods, and assumptions. Proc. Natl. Acad. Sci. USA 2009, 106, 19644-19650. [CrossRef] [PubMed]

22. Bruno, J.F.; Stachowicz, J.J.; Bertness, M.D. Inclusion of facilitation into ecological theory. Trends Ecol. Evol. 2003, 18, 119-125. [CrossRef]

23. Thomsen, M.; McGlathery, K. Facilitation of macroalgae by the sedimentary tube forming polychaete Diopatra cuprea. Estuar. Coast. Shelf Sci. 2005, 62, 63-73. [CrossRef]

24. Hutchinson, G.E. Cold spring harbor symposium on quantitative biology. Concluding Remarks 1957, 22, 415-427.

25. Dayton, P.K.; Tegner, M.J. Catastrophic storms, el niño, and patch stability in a southern california kelp community. Science 1984, 224, 283-285. [CrossRef] [PubMed]

26. Dayton, P.K.; Tegner, M.J.; Edwards, P.B.; Riser, K.L. Temporal and spatial scales of kelp demography: The role of oceanographic climate. Ecol. Monogr. 1999, 69, 219-250. [CrossRef]

27. Elith, J.; Leathwick, J.R. Species distribution models: Ecological explanation and prediction across space and time. Annu. Rev. Ecol., Evol. Syst. 2009, 40, 677-697. [CrossRef]

28. Peterson, A.T.; Vieglais, D.A. Predicting species invasions using ecological niche modeling: New approaches from bioinformatics attack a pressing problem: A new approach to ecological niche modeling, based on new tools drawn from biodiversity informatics, is applied to the challenge of predicting potential species' invasions. BioScience 2001, 51, 363-371.

29. Tyberghein, L.; Verbruggen, H.; Pauly, K.; Troupin, C.; Mineur, F.; De Clerck, O. Bio-oracle: A global environmental dataset for marine species distribution modelling. Glob. Ecol. Biogeogr. 2012, 21, $272-281$. [CrossRef]

30. Gotelli, N.J.; Stanton-Geddes, J. Climate change, genetic markers and species distribution modelling. J. Biogeogr. 2015, 42, 1577-1585. [CrossRef]

31. Graham, M.H.; Kinlan, B.P.; Druehl, L.D.; Garske, L.E.; Banks, S. Deep-water kelp refugia as potential hotspots of tropical marine diversity and productivity. Proc. Natl. Acad. Sci. USA 2007, 104, 16576-16580. [CrossRef] [PubMed]

32. Verbruggen, H.; Leliaert, F.; Maggs, C.A.; Shimada, S.; Schils, T.; Provan, J.; Booth, D.; Murphy, S.; De Clerck, O.; Littler, D.S.; et al. Species boundaries and phylogenetic relationships within the green algal genus codium (bryopsidales) based on plastid DNA sequences. Mol. Phylogenet. Evol. 2007, 44, $240-254$. [CrossRef] [PubMed] 
33. Assis, V.D.L.; Carvalho, T.S.G.; Pereira, V.M.; Freitas, R.T.F.; Saad, C.E.P.; Costa, A.C.; Silva, A.A.A. Environmental enrichment on the behavior and welfare of cockatiels (nymphicus hollandicus). Arq. Bras. Med. Vet. Zootec. 2016, 68, 562-570. [CrossRef]

34. Highsmith, R.C. Floating and algal rafting as potential dispersal mechanisms in brooding invertebrates. Mar. Ecol. Prog. Ser. 1985, 25, 169-179. [CrossRef]

35. Steneck, R.S.; Graham, M.H.; Bourque, B.J.; Corbett, D.; Erlandson, J.M.; Estes, J.A.; Tegner, M.J. Kelp forest ecosystems: Biodiversity, stability, resilience and future. Environ. Conserv. 2003, 29, 436-459. [CrossRef]

36. Dayton, P.K. Ecology of kelp communities. Annu. Rev. Ecol. Syst. 1985, 16, 215-245. [CrossRef]

37. Darwin, C. The descent ofman. In The Great Books of the Western World; Encyclopædia Britannica, Inc.: Chatswood, NSW, Australia, 1871; Volume 49, p. 320.

38. Macaya, E.C.; Zuccarello, G.C. Genetic structure of the giant kelp Macrocystis pyrifera along the southeastern pacific. Mar. Ecol. Prog. Ser. 2010, 420, 103-112. [CrossRef]

39. Griffiths, H.J.; Waller, C.L. The first comprehensive description of the biodiversity and biogeography of antarctic and sub-antarctic intertidal communities. J. Biogeogr. 2016, 43, 1143-1155. [CrossRef]

40. Kuhnemann, O. Algunas consideraciones sobre los bosques de macrocystis pyrifera. Physis 1970, 25, $273-296$.

41. Raffo, M.P.; Eyras, M.C.; Iribarne, O.O. The invasion of undaria pinnatifida to a Macrocystis pyrifera kelp in Patagonia (argentina, south-west atlantic). J. Mar. Biol. Assoc. UK 2009, 89, 1571-1580. [CrossRef]

42. Rothman, M.D.; Mattio, L.; Anderson, R.J.; Bolton, J.J. A phylogeographic investigation of the kelp genus laminaria (laminariales, phaeophyceae), with emphasis on the South Atlantic Ocean. J. Phycol. 2017, 4, 778-789. [CrossRef] [PubMed]

43. Westermeier, R.; Patiño, D.J.; Murúa, P.; Müller, D.G. Macrocystis mariculture in chile: Growth performance of heterosis genotype constructs under field conditions. J. Appl. Phycol. 2011, 23, 819-825. [CrossRef]

44. Ladah, L.B.; Zertuche-González, J.A. Survival of microscopic stages of a perennial kelp (Macrocystis pyrifera) from the center and the southern extreme of its range in the northern hemisphere after exposure to simulated el niño stress. Mar. Biol. 2007, 152, 677-686. [CrossRef]

45. Macaya, E.C.; Boltaña, S.; Hinojosa, I.A.; Macchiavello, J.E.; Valdivia, N.A.; Vásquez, N.R.; Buschmann, A.H.; Vásquez, J.A.; Alonso Vega, J.M.; Thiel, M. Presence of sporophylls in floating kelp rafts of Macrocystis spp. (phaeophyceae) along the chilean pacific coast. J. Phycol. 2005, 41, 913-922. [CrossRef]

46. Hernández-Carmona, G.; Hughes, B.; Graham, M.H. Reproductive longevity of drifting kelp Macrocystis pyrifera (phaeophyceae) in Monterey bay, USA. J. Phycol. 2006, 42, 1199-1207. [CrossRef]

47. Hay, C.H. Durvillaea (bory). In Biology of Economic Seaweeds; SPB Academic Publishing: The Hague, The Netherlands, 1994.

48. Castañeda, V.; Reyes-Bonilla, H. A tropical assemblage of benthic macroalgae on rocky reefs in a temperate zone on the western Baja California peninsula, mexico. Bot. Mar. 2010, 53, 195-203.

49. Marins, B.; Amado-Filho, G.; Barbarino, E.; Pereira-Filho, G.; Longo, L. Seasonal changes in population structure of the tropical deep-water kelp laminaria abyssalis. Phycol. Res. 2014, 62, 55-62. [CrossRef]

50. Emiliani, C. Pleistocene temperatures. J. Geol. 1955, 63, 538-578. [CrossRef]

51. Lüning, K. Seaweeds: Their Environment, Biogeography, and Ecophysiology; John Wiley \& Sons: Hoboken, BJ, USA, 1990; p. 544.

52. Bellard, C.; Bertelsmeier, C.; Leadley, P.; Thuiller, W.; Courchamp, F. Impacts of climate change on the future of biodiversity. Ecol. Lett. 2012, 15, 365-377. [CrossRef] [PubMed]

53. Schiel, D.R.; Foster, M.S. The population biology of large brown seaweeds: Ecological consequences of multiphase life histories in dynamic coastal environments. Annu. Rev. Ecol. Evol. Syst. 2006, 37, 343-372. [CrossRef]

54. Fernández, C. The retreat of large brown seaweeds on the north coast of Spain: The case of Saccorhiza polyschides. Eur. J. Phycol. 2011, 46, 352-360. [CrossRef]

55. Falvey, M.; Garreaud, R.D. Regional cooling in a warming world: Recent temperature trends in the southeast pacific and along the west coast of subtropical South America (1979-2006). J. Geophys. Res. Atmos. 2009, 114, D4. [CrossRef]

56. Bolton, J.; Anderson, R.; Smit, A.; Rothman, M. South African kelp moving eastwards: The discovery of Ecklonia maxima (osbeck) papenfuss at de hoop nature reserve on the south coast of South Africa. Afr. J. Mar. Sci. 2012, 34, 147-151. [CrossRef] 
57. Verbruggen, H.; Tyberghein, L.; Pauly, K.; Vlaeminck, C.; Nieuwenhuyze, K.V.; Kooistra, W.H.C.F.; Leliaert, F.; Clerck, O.D. Macroecology meets macroevolution: Evolutionary niche dynamics in the seaweed halimeda. Glob. Ecol. Biogeogr. 2009, 18, 393-405. [CrossRef]

58. Palumbi, S.R.; Gaines, S.D.; Leslie, H.; Warner, R.R. New wave: High-tech tools to help marine reserve research. Front. Ecol. Environ. 2003, 1, 73-79. [CrossRef]

59. Anderson, A.; Bonaldo, R.; Barneche, D.; Hackradt, C.; Félix-Hackradt, F.; García-Chartón, J.; Floeter, S. Recovery of grouper assemblages indicates effectiveness of a marine protected area in southern brazil. Mar. Ecol. Prog. Ser. 2014, 514, 207-215. [CrossRef]

60. Shefer, S.; Abelson, A.; Mokady, O.; Geffen, E. Red to mediterranean sea bioinvasion: Natural drift through the suez canal, or anthropogenic transport? Mol. Ecol. 2004, 13, 2333-2343. [CrossRef] [PubMed]

61. Facon, B.; Genton, B.J.; Shykoff, J.; Jarne, P.; Estoup, A.; David, P. A general eco-evolutionary framework for understanding bioinvasions. Trends Ecol. Evol. 2006, 21, 130-135. [CrossRef] [PubMed]

62. Anderson, A.B.; Carvalho-Filho, A.; Morais, R.A.; Nunes, L.T.; Quimbayo, J.P.; Floeter, S.R. Brazilian tropical fishes in their southern limit of distribution: Checklist of santa catarina's rocky reef ichthyofauna, remarks and new records. J. Biodivers. Data 2015, 11, 1688. [CrossRef]

63. Olson, B.; Richards, J. Spatial arrangement of tiller replacement in agropyron desertorum following grazing. Oecologia 1988, 76, 7-10. [CrossRef] [PubMed]

64. Peterson, R.G.; Stramma, L. Upper-level circulation in the South Atlantic Ocean. Prog. Oceanogr. 1991, 26, 1-73. [CrossRef]

65. Pereira, M.D.; Schettini, C.A.F.; Omachi, C.Y. Caracterização de feições oceanográficas na plataforma de santa catarina através de imagens orbitais. Rev. Bras. Geofís. 2009, 27, 81-93. [CrossRef]

66. Acha, E.M.; Mianzan, H.W.; Guerrero, R.A.; Favero, M.; Bava, J. Marine fronts at the continental shelves of austral south america. J. Mar. Syst. 2004, 44, 83-105. [CrossRef]

67. Piola, A.R.; Campos, E.J.D.; Möller, O.O.; Charo, M.; Martinez, C. Subtropical shelf front off eastern South America. J. Geophys. Res. Oceans 2000, 105, 6565-6578. [CrossRef]

68. Piola, A.R.; Matano, R.P.; Palma, E.D.; Möller, O.O.; Campos, E.J.D. The influence of the plata river discharge on the western south Atlantic shelf. Geophys. Res. Lett. 2005, 32. [CrossRef]

69. Anderson, A.B. Peixes Tropicais no seu Limite de Distribuição: Dinâmica Temporal da Ictiofauna Recifal no sul do Brasil. Ph.D. Thesis, Universidade Federal de Santa Catarina, Florianópolis, Santa Catarina, Brazil, 2017; p. 202.

70. Horta, P.; Amancio, E.; Coimbra, C.; Oliveira, E. Considerações sobre a distribuição e origem da flora de macroalgas marinhas brasileiras. Hoehnea 2001, 28, 243-265.

71. Spalding, M.D.; Fox, H.E.; Allen, G.R.; Davidson, N.; FerdaÑA, Z.A.; Finlayson, M.A.X.; Halpern, B.S.; Jorge, M.A.; Lombana, A.L.; Lourie, S.A.; et al. Marine ecoregions of the world: A bioregionalization of coastal and shelf areas. BioScience 2007, 57, 573-583. [CrossRef]

72. Pires Gouvêa, L.; Schubert, N.; Dalcuche Leal Martins, C.; Sissini, M.; Ramlov, F.; Regina de Oliveira Rodrigues, E.; Oliveira Bastos, E.; Carvalho Freire, V.; Maraschin, M.; Simonassi, J.; et al. Interactive effects of marine heatwaves and eutrophication on the ecophysiology of a widespread and ecologically important macroalga: Temperature and nutrient effect on macroalgae. Limnol. Oceanogr. 2017, 62, 2056-2075. [CrossRef]

73. Freire, A.S.; Varela, A.R.D.; Fonseca, A.L.D.; Menezes, B.S.; Fest, C.B.; Obata, C.S.; Gorril, C.; Franco, D.; Machado, E.C.; Barros, G.; et al. O ambiente oceanográfico. In Maare-Monitoramento Ambiental da Reserva Biológica Marinha do Arvoredo e Entorno; UFSC-EdUFSC: Florianópolis, Brazil, 2017; Volume 1, pp. 159-197.

74. Fraser, C.I.; Hay, C.H.; Spencer, H.G.; Waters, J.M. Genetic and morphological analyses of the southern bull kelp Durvillaea antarctica (phaeophyceae: Durvillaeales) in New Zealand reveal cryptic species. J. Phycol. 2009, 45, 436-443. [CrossRef] [PubMed]

75. Leal, P.P.; Hurd, C.L.; Roleda, M.Y. Meiospores produced in sori of nonsporophyllous laminae of macrocystis pyrifera (laminariales, phaeophyceae) may enhance reproductive output. J. Phycol. 2014, 50, 400-405. [CrossRef] [PubMed]

76. Elith, J.; Graham, C.; Anderson, R.; Dudık, M.; Ferrier, S. Novel methods improve prediction of species' distribution models. Ecography 2006, 32, 66-77. [CrossRef]

77. Philips, S.J.; Dudík, M. Modeling of species distributions with maxent: New extensions and a comprehensive evaluation. Ecography 2008, 31, 161-175. [CrossRef] 
78. Merow, C.; Smith, M.J.; Silander, J.A. A practical guide to maxent for modeling species' distributions: What it does, and why inputs and settings matter. Ecography 2013, 36, 1058-1069. [CrossRef]

79. Hernandez, P.A.; Graham, C.H.; Master, L.L.; Albert, D.L. The effect of sample size and species characteristics on performance of different species distribution modeling methods. Ecography 2006, 29, 773-785. [CrossRef]

80. Assis, J.; Coelho, N.C.; Lamy, T.; Valero, M.; Alberto, F.; Serrão, E.Á. Deep reefs are climatic refugia for genetic diversity of marine forests. J. Biogeogr. 2016, 43, 833-844. [CrossRef]

81. Assis, J.; Araújo, M.B.; Serrão, E.A. Projected climate changes threaten ancient refugia of kelp forests in the north Atlantic. Glob. Chang. Biol. 2017. [CrossRef] [PubMed]

82. O'brien, R.M. A caution regarding rules of thumb for variance inflation factors. Qual. Quant. 2007, 41, 673-690. [CrossRef]

83. Segurado, P.; Araújo, M.B.; Kunin, W. Consequences of spatial autocorrelation for niche-based models. J. Appl. Ecol. 2006, 43, 433-444. [CrossRef]

84. Patrão, C.; Assis, J.; Rufino, M.; Silva, G.; Jordaens, K.; Backeljau, T.; Castilho, R. Habitat suitability modelling of four terrestrial slug species in the iberian peninsula (arionidae: Geomalacus species). J. Molluscan Stud. 2015, 81, 427-434. [CrossRef]

85. Phillips, S.J.; Dudík, M.; Elith, J.; Graham, C.H.; Lehmann, A.; Leathwick, J.; Ferrier, S. Sample selection bias and presence-only distribution models: Implications for background and pseudo-absence data. Ecol. Appl. 2009, 19, 181-197. [CrossRef] [PubMed]

86. Peterson, A.T. Ecological niche conservatism: A time-structured review of evidence. J. Biogeogr. 2011, 38, 817-827. [CrossRef]

87. Muscarella, R.; Galante, P.J.; Soley-Guardia, M.; Boria, R.A.; Kass, J.M.; Uriarte, M.; Anderson, R.P. Enmeval: An $r$ package for conducting spatially independent evaluations and estimating optimal model complexity for maxent ecological niche models. Methods Ecol. Evol. 2014, 5, 1198-1205. [CrossRef]

88. Madon, B.; Warton, D.I.; Araújo, M.B. Community-level vs. species-specific approaches to model selection. Ecography 2013, 36, 1291-1298. [CrossRef]

89. Allouche, O.; Tsoar, A.; Kadmon, R. Assessing the accuracy of species distribution models: Prevalence, kappa and the true skill statistic (TSS). J. Appl. Ecol. 2006, 43, 1223-1232. [CrossRef]

90. Phillips, S.J.; Anderson, R.P.; Schapire, R.E. Maximum entropy modeling of species geographic distributions. Ecol. Model. 2006, 190, 231-259. [CrossRef]

91. Fraser, C.I.; Winter, D.J.; Spencer, H.G.; Waters, J.M. Multigene phylogeny of the southern bull-kelp genus durvillaea (phaeophyceae: Fucales). Mol. Phylogenet. Evol. 2010, 57, 1301-1311. [CrossRef] [PubMed]

92. Tala, F.; Velásquez, M.; Mansilla, A.; Macaya, E.C.; Thiel, M. Latitudinal and seasonal effects on short-term acclimation of floating kelp species from the south-east pacific. J. Exp. Mar. Biol. Ecol. 2016, 483, 31-41. [CrossRef]

93. Coyer, J.A.; Smith, G.J.; Andersen, R.A. Evolution of Macrocystis spp. (phaeophyceae) as determined by its1 and its2 sequences1. J. Phycol. 2001, 37, 574-585. [CrossRef]

94. Van den Hoek, C.; Donze, M. Algal phytogeography of the European Atlantic coasts. Blumea 1967, 15, 63-85.

95. Smith, S.D. Kelp rafts in the southern ocean. Glob. Ecol. Biogeogr. 2002, 11, 67-69. [CrossRef]

96. Garden, C.J.; Currie, K.; Fraser, C.I.; Waters, J.M. Rafting dispersal constrained by an oceanographic boundary. Mar. Ecol. Prog. Ser. 2014, 501, 297-302. [CrossRef]

97. Edwards, M.S.; Kim, K.Y. Diurnal variation in relative photosynthetic performance in giant kelp Macrocystis pyrifera (phaeophyceae, laminariales) at different depths as estimated using pam fluorometry. Aquat. Bot. 2010, 92, 119-128. [CrossRef]

98. Tokinaga, H.; Tanimoto, Y.; Xie, S.-P. Sst-induced surface wind variations over the brazil-malvinas confluence: Satellite and in situ observations. J. Clim. 2005, 18, 3470-3482. [CrossRef]

99. Cataldi, M.; Caro, L.D.; Schifanella, C. Emerging topic detection on twitter based on temporal and social terms evaluation. In Proceedings of the Tenth International Workshop on Multimedia Data Mining, Washington, DC, USA, 25 July 2010; pp. 1-10.

100. De Souza, R.B.; Mata, M.M.; Garcia, C.A.; Kampel, M.; Oliveira, E.N.; Lorenzzetti, J.A. Multi-sensor satellite and in situ measurements of a warm core ocean eddy south of the brazil-malvinas confluence region. Remote Sens. Environ. 2006, 100, 52-66. [CrossRef] 
101. Rothäusler, E.; Gómez, I.; Karsten, U.; Tala, F.; Thiel, M. Physiological acclimation of floating macrocystis pyrifera to temperature and irradiance ensures long-term persistence at the sea surface at mid-latitudes. J. Exp. Mar. Biol. Ecol. 2011, 405, 33-41. [CrossRef]

102. Clendenning, K. Organic productivity in kelp areas. Nova Hedwigia 1971, 32, 259-263.

103. Colombo-Pallotta, M.F.; García-Mendoza, E.; Ladah, L.B. Photosynthetic performance, light absorption, and pigment composition of Macrocystis pyrifera (laminariales, phaeophyceae) blades from different depths. J. Phycol. 2006, 42, 1225-1234. [CrossRef]

104. Cheung, W.W.L.; Lam, V.W.Y.; Sarmiento, J.L.; Kearney, K.; Watson, R.; Pauly, D. Projecting global marine biodiversity impacts under climate change scenarios. Fish Fish. 2009, 10, 235-251. [CrossRef]

105. Reed, D.; Washburn, L.; Rassweiler, A.; Miller, R.; Bell, T.; Harrer, S. Extreme warming challenges sentinel status of kelp forests as indicators of climate change. Nat. Commun. 2016, 7. [CrossRef] [PubMed]

106. Ladah Lydia, B.; Zertuche-González José, A. Giant kelp (Macrocystis pyrifera) survival in deep water (25-40 m) during el niño of 1997-1998 in baja california, mexico. Bot. Mar. 2004, 47, 367-372. [CrossRef]

107. Pehlke, C.; Bartsch, I. Changes in depth distribution and biomass of sublittoral seaweeds at Helgoland (North Sea) between 1970 and 2005. Clim. Res. 2008, 37, 135-147. [CrossRef]

108. Yoneshigue-Valentin, Y. In the Life Cycle of Laminaria abyssalis (Laminariales, phaeophyta) in Culture. In Proceedings of the Thirteenth International Seaweed Symposium, Vancouver, BC, Canada, 13-18 August 1989; Springer: Berlin, Germany, 1990; pp. 461-466.

109. Yoneshigue-Valentin, Y.; Mitchell, G.J.; Gurgel, C.F.D. Quelques observations préliminaires sur les macroalgues de la plateforme continentale du sudest brésilien. Acta Bot. Gall. 1995, 142, 161-165. [CrossRef]

110. O'Hara, T.D.; Consalvey, M.; Lavrado, H.P.; Stocks, K.I. Environmental predictors and turnover of biota along a seamount chain. Mar. Ecol. 2010, 31, 84-94. [CrossRef]

111. Williams, S.L.; Smith, J.E. A global review of the distribution, taxonomy, and impacts of introduced seaweeds. Annu. Rev. Ecol. Evol. Syst. 2007, 38, 327-359. [CrossRef]

112. Azevedo, C.A.A.D.; Cassano, V.; Júnior, P.A.H.; Batista, M.B.; Oliveira, M.C.D. Detecting the non-native Grateloupia turuturu (halymeniales, rhodophyta) in southern Brazil. Phycologia 2015, 54, 451-454. [CrossRef]

113. Edwards, M.; Hernandez-Carmona, G. Delayed recovery of giant kelp near its southern range limit in the north pacific following el niño. Mar. Biol. 2005, 147, 273-279. [CrossRef]

114. Nyberg, C.D.; Wallentinus, I. Can species traits be used to predict marine macroalgal introductions? Biol. Invasions 2005, 7, 265-279. [CrossRef]

115. South, P.M.; Lilley, S.A.; Tait, L.W.; Alestra, T.; Hickford, M.J.H.; Thomsen, M.S.; Schiel, D.R. Transient effects of an invasive kelp on the community structure and primary productivity of an intertidal assemblage. Mar. Freshw. Res. 2015, 67, 103-112. [CrossRef]

116. Thompson, G.A.; Schiel, D.R. Resistance and facilitation by native algal communities in the invasion success of Undaria pinnatifida. Mar. Ecol. Prog. Ser. 2012, 468, 95-105. [CrossRef]

117. Valentine, J.P.; Johnson, C.R. Establishment of the introduced kelp Undaria pinnatifida in Tasmania depends on disturbance to native algal assemblages. J. Exp. Mar. Biol. Ecol. 2003, 295, 63-90. [CrossRef]

118. Bernhardt, J.R.; Leslie, H.M. Resilience to climate change in coastal marine ecosystems. Annu. Rev. Mar. Sci. 2013, 5, 371-392. [CrossRef] [PubMed]

119. Challinor, A.J.; Adger, W.N.; Benton, T.G. Climate risks across borders and scales. Nat. Clim. Chang. 2017, 7, 621-623. [CrossRef]

120. Barry, J.P.; Baxter, C.H.; Sagarin, R.D.; Gilman, S.E. Climate-related, long-term faunal changes in a California rocky intertidal community. Science 1995, 267, 672-675. [CrossRef] [PubMed]

121. Wheeler, W.N. Effect of boundary layer transport on the fixation of carbon by the giant kelp Macrocystis pyrifera. Mar. Biol. 1980, 56, 103-110. [CrossRef]

(C) 2018 by the authors. Licensee MDPI, Basel, Switzerland. This article is an open access article distributed under the terms and conditions of the Creative Commons Attribution (CC BY) license (http://creativecommons.org/licenses/by/4.0/). 